Deep Sea Research Part II: Topical Studies in Oceanography

August 2017, Volume 142, Pages 64-74

http://dx.doi.org/10.1016/i.dsr2.2017.01.009

http://archimer.ifremer.fr/doc/00369/47974/

(c) 2017 Elsevier Ltd. All rights reserved.

\title{
Organic carbon accumulation in modern sediments of the Angola basin influenced by the Congo deep sea fan
}

\author{
Baudin François ${ }^{1,{ }^{*}}$, Martinez Philippe ${ }^{2}$, Dennielou Bernard ${ }^{3}$, Charlier Karine ${ }^{2}$, Marsset Tania ${ }^{3}$, \\ Droz Laurence ${ }^{4}$, Rabouille Christophe ${ }^{5}$
}

${ }^{1}$ Sorbonne Universités, UPMC-Univ. Paris 06, CNRS, Institut des Sciences de la Terre (ISTeP), UMR 7193, 4 place Jussieu, 75005 Paris, France

2 Université de Bordeaux, CNRS, Environnements et Paléoenvironnements Océaniques et

Continentaux (EPOC), UMR 5805, Allée Geoffroy St Hilaire, 33615 Pessac Cedex, France

${ }^{3}$ IFREMER-Département REM, Unité des Géosciences Marines, 29280 Plouzané, France

${ }^{4}$ Institut Universitaire Européen de la Mer, CNRS, Laboratoire Domaines Océaniques, UMR 6538, rue Dumont d'Urville, 29280 Plouzané, France

${ }^{5}$ Laboratoire des Sciences du Climat et de l'Environnement (LSCE), UMR 8212- CEA-CNRS-UVSQ et IPSL, Université Paris-Saclay, Bât. 12, avenue de la Terrasse, 91198 Gif sur Yvette, France

*Corresponding author : François Baudin, email address : francois.baudin@upmc.fr

\begin{abstract}
:
Geochemical data (total organic carbon-TOC content, $013 \mathrm{Corg}, \mathrm{C}: \mathrm{N}$, Rock-Eval analyses) were obtained on 150 core tops from the Angola basin, with a special focus on the Congo deep sea fan. Combined with the previously published data, the resulting dataset (322 stations) shows a good spatial and bathymetric representativeness. TOC content and $\delta 13 \mathrm{Corg}$ maps of the Angola basin were generated using this enhanced dataset. The main difference in our map with previously published ones is the high terrestrial organic matter content observed downslope along the active turbidite channel of the Congo deep sea fan till the distal lobe complex near 5,000 m of water-depth. Interpretation of downslope trends in TOC content and organic matter composition indicates that lateral particle transport by turbidity currents is the primary mechanism controlling supply and burial of organic matter in the bathypelagic depths.
\end{abstract}

\section{Introduction}

Marine sediments represent the largest reservoir of organic carbon on earth and organic matter (OM) burial in marine sediments plays a key-role in the carbon cycle (Berner, 1982). The major part of OM in marine sediments derived from phytoplankton, although only a very small proportion of surface water primary production, reaches the deep ocean, owing to intense remineralization during 


\section{ACCEPTED MANUSCRIPT}

settling of particles and at the seafloor. Moreover, the export and accumulation of marine $\mathrm{OM}$ in deep-sea sediments vary significantly from place to place (François et al., 2002; Jahnke, 1996; Seiter et al., 2004 among others). Marine OM concentration is generally higher along continental margins where nutrients are available, particularly in upwelling areas, and is lower in abyssal plains due to decreasing primary productivity with increasing distance from the coast and due to the longer transit time through water column because of larger water depth.

Terrestrial OM transported by rivers -and dust as a subordinate conveyor- also contributes to the burial of organic carbon in marine sediments (Bianchi et al., 2014; Blair and Aller, 2012; Dagg et al., 2004; Degens et al., 1991; Schlünz and Schneider, 2000). Although terrestrial OM is more resistant to remineralization than marine $\mathrm{OM}$, it undergoes an intense recycling along the continental margins (Burdige, 2005). Most of the terrestrial OM preserved in marine sediments is stored in deltaic environments and the remainder is dispersed along continental margins and deep oceanic settings where it is mixed with autochthonous marine OM (Berner, 1982; Burdige, 2005; Hedges and Keil, 1995). Only rivers directly connected to the deep ocean by a submarine canyon may transfer high amounts of terrestrial OM into the abyssal plains.

This is the case of the Congo River, the second largest river in the world in terms of fluvial discharge (Kinga-Mouzeo, 1986), which exports large amounts of sediment to the eastern tropical part of the southern Atlantic Ocean, the Angola basin (Fig. 1). The influence of the Congo River for the OM export to the Angola basin has been recognized long time ago. However, previous studies suggested that only shelf and upper slope deposits in front of the Congo River have high continental-marine OM ratio (1:1) while sediments in water depths greater than $700 \mathrm{~m}$ contain predominantly marine OM (Mollenhauer et al., 2004; Müller et al., 1994; Seiter et al., 2004).

Since 1992, the Congo turbidite system was intensely studied by the French community. Several oceanographic campaigns were operated on this area: Guiness 1 and 2 (Cochonat, 1993; Cochonat and Robin, 1992), Zaïango 1 and 2 (Cochonat, 1998; Savoye, 1998), Zaïrov (Savoye and Ondréas, 2000), Biozaïre (Khripounoff, 2003; Sibuet, 2001a, 2001b), Reprezaï (Marsset and Droz, 2010), WACS (Olu, 2011) and Congolobe (Rabouille, 2011). Several thousands of kilometers of seismic lines, around $250,000 \mathrm{~km}^{2}$ of bathymetric survey, moorings with sediment traps and current-meters, dives with submarine vehicles, core samplings and in situ geochemical measurements were acquired during these campaigns. A significant amount of data and samples was obtained which allows a good description and understanding of the whole Congo deep sea fan (refer to Babonneau et al., 2004; Droz et al., 2003; Marsset et al., 2009; Migeon et al., 2004; Picot et al., 2016, and Savoye et al., 2009 with references therein). One hundred and fifty sediment cores were collected in different parts of the Congo turbidite system, from the canyon head to the terminal lobe complex, by ca. 5,000 m of water-depth. The organic geochemical analyses of these cores significantly increase the available 


\section{ACCEPTED MANUSCRIPT}

dataset of OM content in surface sediments along the Congo turbidite system and enable to refine the total organic carbon (TOC) map of the Angola basin, especially concerning the areal extent of the Congo influence. The present study reports the geochemical results obtained on 150 core tops, discusses the depositional patterns in $\mathrm{OM}$ along the Congo turbidite system and examines the downslope trends in TOC and OM composition in the Angola basin.

\section{Study area}

The Angola basin extends in the equatorial and tropical southeastern Atlantic Ocean between the Equator and $15^{\circ} \mathrm{S}$ and $0^{\circ}$ and $13^{\circ} \mathrm{E}$ (Fig. 1). The surface water circulation in this basin is dominated by the Angola Current which forms the eastern branch of a large, cyclonic gyre in the Gulf of Guinea. It is formed by the southeast branch of the South Equatorial Countercurrent and the southward-turning waters from the north branch of the Benguela Oceanic Current. The modern distribution of primary production in this area is mainly characterized by oligotrophic waters in the southern part of the Angola basin with annual primary production less than $150 \mathrm{~g} \mathrm{C} . \mathrm{m}^{-2}$ (Antoine et al., 1996). By contrast, the northern part of the basin is characterized by higher primary production levels as the Congo River delivers large freshwater input with elevated nutrient concentration. The resulting plume extends in surface up to $800 \mathrm{~km}$ from the coastline (Cadée, 1984) and is deflected to the northwest by the South Equatorial Current. Annual primary production in this area may reach $400 \mathrm{~g} \mathrm{C}^{-\mathrm{m}^{-2}}$ (Antoine et al., 1996). In addition, some wind-driven seasonal upwellings impact the local productivity along the coast with annual primary production levels up to $700 \mathrm{~g} \mathrm{C} . \mathrm{m}^{-2}$ (Antoine et al., 1996; Schneider et al., 1997).

The deep-water circulation in the Angola basin is dominated by the oxygen-rich North Atlantic Deep Water (NADW). NADW flows southward at depth along the western margin of South Africa(Reid, 1996).

Modern surface sediments in the Angola basin are classified as nannofossil oozes (Archer, 1996), with minor contributions of clay and siliceous microfossils. Clays are dominant below the calcite compensation depth (CCD), which presently lies at a depth of ca. 5,000 m in the Atlantic Ocean (between 4,800 and 5,600 $\mathrm{m}$ in the Angola basin according to Jansen et al., 1984). Clayey and silty sediments are also associated to the mud-rich Congo deep sea fan.

This Congo fan is developed on the adjacent continental margin off the mouth of the Congo River and is one of the world's largest active deep-sea turbidite systems, with a surface estimated to $330,000 \mathrm{~km}^{2}$ (Savoye et al., 2000, 2009). The turbiditic activity results from the direct connection between the Congo River estuary and a canyon head that allows direct transfer of sediment into the deep-sea via a single channel. The presently active channel-levee system, which extends $760 \mathrm{~km}$ 


\section{ACCEPTED MANUSCRIPT}

westward off the Congo River mouth, was subject of several detailed studies (Babonneau, 2002; Babonneau et al., 2002, 2010; Bonnel, 2005; Droz et al., 1996, 2003; Marsset et al., 2009; Picot et al., 2016; Savoye et al., 2000, 2009). Evidences for the occurrence of turbidity currents in the canyon/channel include submarine cable breaks (Heezen et al., 1964) and direct sampling of turbidity currents by current-meters and sediment traps between 2001 and 2004 (Khripounoff et al., 2003; Vangriesheim et al., 2009). The frequency of turbidity events is estimated at about 60 per century (Heezen et al., 1964). The slope of the channel floor decreases from 1.5 to $0.2 \%$ down channel. The channel is over-incised, with an incision depth ranging from $200 \mathrm{~m}$ at 3,000 m-depth to $100 \mathrm{~m}$ at 4,300 m-depth (Babonneau et al., 2002; Savoye et al., 2000). Though the base of turbidity currents remains confined within the canyon/channel, the upper part can overflow the channel flanks and build symmetric levees on both sides of the channel. The size of the channel-levee system (channel relief, levee thickness and levee extension) decreases downslope toward the distal part of the turbidite system, where the channel disappears and feeds terminal lobes (Savoye et al., 2000). The present-day active turbidite system ends as a complex of five partly stacked lobes, at a water depth of $\sim 5,000 \mathrm{~m}$. The terminal lobe complex was particularly studied during the Congolobe campaign (Rabouille, 2011; Rabouille et al., 2016).

\section{Material and methods}

\subsection{Database}

The database was firstly built by compiling surface sediment OM data retrieved from the literature. It includes data published by Bickert and Wefer (1996), Bongo-Passi (1984), Cwienk (1986), Emelyanov and Romankevich (1979), Kolla et al. (1979), Jansen et al. (1984), Lisitzin et al. (1975), Mollenhauer et al. (2004), Müller et al. (1994), Romankevich (1994), Rühlemann et al. (1999), Schneider et al (1997), Wagner et al. (2004), Weijers et al. (2009) and Westerhausen et al. (1993). Most of these data were previously compiled by Mollenhauer et al. (2004) or Seiter et al. (2004) and are available on PANGAEA (Mollenhauer et al. 2004). The resulting database, including 158 stations, was quality controlled considering redundancies and inconsistencies. The TOC contents in this dataset were expressed in weight percent of dry, salt-free sediment (Mollenhauer et al., 2004). Sampling devices and methods of measurement are diverse as described in the references listed above, but TOC content was generally determined by elemental analysis.

This database was then enriched with OM data acquired on surface sediments (i.e. first centimeter) recovered in the Congo deep sea fan, the Ogooué turbidite system and other places in the Angola basin. It includes 32 data points published by Baudin et al. (2010), Biscara et al. (2011), Dalibard et al. (2014), Rabouille et al. (2009), Stetten et al. (2015), Treignier (2005) and Treignier et al. (2006). 


\section{ACCEPTED MANUSCRIPT}

Finally, 132 additional core tops were sampled and analyzed as follow to complete the dataset (Table 1). In total 322 stations in the Angola basin were compiled for the present study.

\subsection{Samples}

The cores were recovered between 1992 and 2012 during different cruises operated by Ifremer to survey the Congo deep sea fan. These cores penetrated different depositional environments characteristics of the Congo turbiditic facies, including channel deposits (16.2\% of the total cores), levee deposits $(10.2 \%)$, lobe deposits $(32.5 \%)$, hemipelagic deposits $(38.5 \%)$ and rare contouritic facies (2.6\%). Several tools were used for coring, including gravity core, multitube, and remotely operated vehicle core-tube devices as reported in Table 1. For gravity cores, it should be kept in mind that the first centimeters or decimeters of the sediment were washed over when the tool penetrated the seafloor and during corer handling aboard ship. The same problem happens for some stations considered in previous studies (e.g. Mollenhauer et al., 2004). For all available and appropriate cores, 5 to $8 \mathrm{cc}$ of the first centimeter $(0-1 \mathrm{~cm}$ interval) were sampled. This sampling interval may be reduced $(0-0.5 \mathrm{~cm})$ or skip to the second or third centimeter when the top of the core was disturbed (Table 1).

The cores from Reprezaï, WACS and Congolobe campaigns were sampled just after retrieval, whereas cores from Guiness, Zaïango, and Zaïrov campaigns were stored several years at room temperature before sampling. All samples were rinsed with deionized-water to eliminate salt (which may generate disturbance during Rock-Eval analysis), dried in an oven at $50^{\circ} \mathrm{C}$ for $12 \mathrm{~h}$ and crushed in an agate mortar to obtain a fine and homogeneous powder.

\subsection{Analytical methods}

Pyrolytic analyses were carried out using a Rock-Eval 6 Turbo device (at Sorbonne-Universities), operating in a mode which is devoted to recent sediments (Baudin et al., 2015). This mode necessitates to start the pyrolysis at $180^{\circ} \mathrm{C}$ to avoid thermal decomposition of the most labile components of the OM. Among the parameters delivered by Rock-Eval analysis, two were particularly examined here: total organic carbon content (TOC, in wt \%) and hydrogen index $(\mathrm{HI}$, in $\mathrm{mg} \mathrm{HC} . \mathrm{g}^{-1} \mathrm{TOC}$ ) corresponding to the quantity of pyrolyzable organic compounds ( $\mathrm{S} 2$ peak) relative to TOC. The precision for the parameters is $\pm 0.1 \%$ for TOC and $\pm 10 \mathrm{mg} \mathrm{HC} . \mathrm{g}^{-1} \mathrm{TOC}$ for $\mathrm{HI}$.

$\mathrm{C}: \mathrm{N}$ atomic ratios, and stable isotope composition of carbon were determined (at Bordeaux University) by on-line combustion in a Thermo Fischer Flash 2000 Elemental Analyzer connected to an Isoprime isotope ratio mass spectrometer. Prior to isotopic measurements, samples were acidified with $1 \mathrm{~N} \mathrm{HCl}$ to remove the inorganic carbon then rinsed with deionized water. The ${ }^{13} \mathrm{C} /{ }^{12} \mathrm{C}$ ratio is expressed using the conventional $\delta$ notation relative to the standard Vienna Pee Dee 


\section{ACCEPTED MANUSCRIPT}

Belemnite (V-PDB). The analytical precisions are $\pm 0.15 \%$ for $\delta^{13} \mathrm{Corg}$. C:N atomic ratios were obtained by measuring total organic carbon (TOC) and total nitrogen (TN) on acidified samples.

\subsection{Mapping method}

Based on the previously published dataset and our complete dataset (322 stations), TOC content maps of the Angola basin were generated using the Surfer@ software. The natural neighbor gridding method, without any anisotropy, was used as this method is well adapted with dataset having dense data in some areas and sparse data in other ones. Although a detailed discussion of the statistical methods is beyond the scope of this study, the natural neighbor method estimates the grid node value by finding the closest subset of input data points to a grid node and then applying weight to each. The natural neighbor method does not extrapolate values beyond the range of data and it does not generate nodes in areas without data. We used geographical coordinates for mapping (= equaldistance projections) that may introduce a bias due to latitudinal distortion in the grid. However, because the Angola basin is situated near the Equator, this distortion is very limited and can be disregarded. The relatively coarse spatial resolution of our grid does not allow high resolution of areas with highly variable TOC content, such as coastal upwelling areas and the distal lobe complex zone. The true TOC content at individual stations in these areas may exceed the values reported on the map, because average values are calculated over a larger area for the coarse grid used here. Finally, due to insufficient spatial resolution, some areas are blanked during the gridding procedure and are left white in the map. This is the case for the OM composition map as only $159 \delta^{13}$ Corg data points are available in the entire Angola basin.

\section{Results and discussion}

\subsection{Representativeness of the dataset}

The seafloor of the Angola basin, as shown on figure 1, covers a total surface of $\sim 1.510^{6} \mathrm{~km}^{2}$ with $82 \%$ of this surface being in abyssal depths $(>3,000 \mathrm{~m})$. Because oceanographic studies are generally focused on shelves and slopes, the data density is much higher in these zones compared to the wide basin areas. In addition, the data density is higher in the central part of the Angola basin (between $3^{\circ}$ and $9^{\circ} \mathrm{S}$ ), just in front of the Congo River mouth, than in northern (between $0^{\circ}$ and $3^{\circ} \mathrm{S}$ ) or southern (between $9^{\circ}$ to $15^{\circ} \mathrm{S}$ ) parts of the basin.

Considering the central part alone, where the influence of the Congo deep sea fan is obvious, the seafloor surface reaches $600,000 \mathrm{~km}^{2}$, namely $40 \%$ of the entire surface of the Angola basin, but includes $78 \%$ of the studied stations. In the studies of Mollenhauer et al. (2004) and Seiter et al. (2004), $68 \%$ of the sites reported in this central part were distributed at water depths above $3,000 \mathrm{~m}$ 


\section{ACCEPTED MANUSCRIPT}

(shelves and slopes), thus representing only $27 \%$ (1 deep station for 2.5 shallow stations) of the Angola basin, and above all, omitting its deepest part (Fig. 2).

We here fill this gap by doubling the number of stations, especially in the deepest part of the Angola basin. The relatively shallow depths $(<3,000 \mathrm{~m})$ are still slightly over-represented compared to abyssal and bathyal depths $(>3,000 \mathrm{~m})$ but the bathymetric distribution of our stations better matches the surface distribution of the studied areas (Fig. 2). Thus, $62 \%$ of the studied sites are located in abyssal depths $(>3,000 \mathrm{~m})$ which cover $73 \%$ of the seafloor surface of that part of the Angola basin.

\subsection{Distribution of TOC content in surface sediments of the Angola basin}

The maps of TOC content in surface sediments of the Angola basin are shown in figure 3 . As already reported by previous authors (Lisitzin et al., 1975; Mollenhauer et al., 2004; Romankevich, 1994, Rühlemann et al., 1999; Seiter et al., 2004), high TOC contents, up to $5 \%$ of total dry and salt-free weight, are observed along the upper slope of the West African continental margin. The highly productive surface waters related to the Angola/Benguela front (near $13-16^{\circ} \mathrm{S}$ ), seasonal upwellings and nutrient-rich freshwater outflow from the Congo River (Voituriez and Herbland, 1981), are responsible for this extremely high sedimentary TOC contents. Surprisingly, the upper slope off Gabon $\left(0-2^{\circ} \mathrm{S}\right)$, which is characterized by high primary production levels (Antoine et al., 1996; Berger, 1989), does not coincide with high TOC values in surface sediments. This has been attributed to dilution of the OM by carbonate and/or biogenic silica (Lisitzin et al., 1975).

The shelf and upper slope deposits in front of the Congo River mouth contain high proportions of terrestrial OM. Our new data set emphasized the high TOC content observed downslope at the emplacement of the Late Quaternary Congo fan (Fig 3b), visible on the seabed morphology by a network of abandoned channels (Droz et al. 2003; Savoye et al. 2000) and along the active turbidite channel of the Congo deep sea fan (Babonneau et al. 2002; Savoye et al. 2009), a feature not shown previously (Mollenhauer et al., 2004; Seiter et al., 2004, Fig. 3a). This is particularly apparent near $5,000 \mathrm{~m}$ of water-depth in the distal part of the fan, where our map shows a butterfly-like positive anomaly of OM. Though the two "wings" are defined by only a limited number of stations therefore questioning their representativeness, the "body" is defined by several tens of stations and is unquestionable. Surprisingly, TOC values as high as $5 \mathrm{wt} \%$ are observed at these great depths, where the terminal lobe complex of the presently active turbidite system is developed (red rectangle on Fig. 3a). The exceptional organic richness of this zone was first discovered by Rabouille et al. (2009) who analyzed a core located in the channel just at the entrance of the lobe complex. After the WACS and Congolobe campaigns (Rabouille et al., this volume), several hundreds of geochemical results confirm 


\section{ACCEPTED MANUSCRIPT}

the extremely high TOC contents of the lobe sediments (Baudin et al., this volume; Stetten et al., 2015).

High TOC contents are found in the upfan zone of the Congo turbidite system too. Near $4,000 \mathrm{~m}$ of water-depth, where the channel-levee systems are well developed (Babonneau et al., 2002), the surface sediments contain 2.5 to 3 wt\% TOC (Baudin et al., 2010).

Our data clearly show that organic depocenters are dependent on the bathymetry, as illustrated in figure 4. A significant enrichment in TOC is noticed in the upper slope areas between 200 and 1,000 m of water-depth. In this bathymetric interval, $80 \%$ of the studied stations (59 data points) exhibit TOC higher than $2 \%$. As mentioned above, this enrichment is related to coastal upwellings which developed along the West Africa and to the lateral transport of OM by nepheloid layers (Inthorn et al., 2006). Below $1,000 \mathrm{~m}$ of water-depth the TOC content is decreasing with increasing depth. For instance at the toe of slope between 3,000 and $4,000 \mathrm{~m}$ of water-depth, only $30 \%$ of the studied stations (47 data points) exhibit TOC higher than $2 \%$. A second enrichment is obvious at abyssal depths (from 4,000 to $5,000 \mathrm{~m}$ and deeper) which is related to the Congo turbidite system. $60 \%$ of the studied stations (105 data points) in the range of 4,000-5,000 m of water-depth display TOC contents higher than $2 \%$ and some surface sediment samples may contain up to $5 \%$ TOC (Fig. 4).

\subsection{Source of organic matter in surface sediments of the Angola basin}

The identification and quantification of OM sources, whether continental or marine, in marine sediments are always difficult because several parameters influence the bulk and molecular characteristics of the preserved OM.

Information on the origin of OM can be determined by pyrolytic measurements by the mean of the Hydrogen Index ( $\mathrm{HI})$ parameter which approximates the $\mathrm{H} / \mathrm{C}$ atomic ratio defined on kerogen (Espitalié et al., 1985; Peters, 1986; Tissot and Welte, 1984). According to the low range of HI values (73-296 mg HC.g ${ }^{-1}$ TOC, Table 1), the OM of the studied samples (147 data points) could be mainly attributed to Type III (Fig. 5). This type is usually related to continental higher-plants debris, but oxidized marine OM (Type II) shows similar HI values (Espitalié et al., 1985, Peters, 1986), especially in recent marine sediments (Baudin et al., 2015). Consequently, the Rock-Eval parameter is here inappropriate to discriminate between marine and terrestrial OM sources.

C: $\mathrm{N}$ ratios (128 data points) show a wide range with values between 10.1 and 24.0 and a mean C:N ratio around 14.1. Such values are indicative of a mixture of marine phytoplankton whose C:N ratio is close to the Redfield ratio ( $\mathrm{C:N} \sim 6.6$ ), and terrigeneous sources with higher $\mathrm{C}: \mathrm{N}$ values. For the Congo River, $\mathrm{C}: \mathrm{N}$ signature ranges from 12.5 to 20.6 on average in fine riverine particulate $\mathrm{OM}$ and up to 27.1 in coarse particulate OM (Spencer et al., 2012). C:N ratios of samples and end-members are often used in linear mixing equations to estimate the fraction of continentally derived TOC in 


\section{ACCEPTED MANUSCRIPT}

sedimentary environments. Nevertheless, because continental OM is relatively depleted in nitrogen, the fraction of terrestrially derived $\mathrm{OM}$ has been systematically underestimated by using C:N mixing lines (Perdue and Koprivnjak, 2007). Moreover, because nitrogen is preferentially consumed during the oxidation of marine $\mathrm{OM}$, the $\mathrm{C}: \mathrm{N}$ ratio of altered marine material deviates from the initial Redfield ratio. Then it is hazardous to calculate a marine or terrestrial source contribution in surface sediments using only their $\mathrm{C}: \mathrm{N}$ ratio signature.

In contrast, the carbon isotopic composition appears a more relevant parameter to estimate the contribution of the two main sources of OM in our dataset. $\delta^{13}$ Corg values (110 data points) range between -19.5 and $-28.0 \%$. If we assume that $\delta^{13}$ Corg of marine OM is $-19.5 \%$ o for that part of the equatorial Atlantic Ocean and the detrital end-member is $-27.8 \%$ as reported by Spencer et al. (2012) for the mean carbon isotopic ratio of OM delivered by the Congo River, the terrestrial organic fraction in the studied core-tops ranges from 0 to $100 \%$. The frequency distribution of the $\delta^{13} \mathrm{Corg}$ datapoints displays a bimodal distribution (Fig. 6). The first mode, around $-22 \%$, suggests that the $\mathrm{OM}$ in surface sediments is dominated by marine phytoplanktonic OM whereas the second, around $26 \%$, denotes a dominance of C3 higher-plants in the OM preserved in marine surface sediments.

\subsection{Influence of turbidite activity for dispersion of terrestrial organic matter}

An E-W trend in the enrichment in OM content of surface sediments of the Angola basin is visible off the Congo River mouth (Fig. 3b). This trend is clearly related to the turbiditic spillover which facilitates the transport and accumulation of $\mathrm{OM}$ along the active turbiditic channel and the terminal lobes of the Congo deep sea fan. The $\delta^{13} \mathrm{Corg}$ map of the Angola basin shows that the terrestrial OM (more negative $\delta^{13} \mathrm{Corg}$ ) is also preferentially distributed along the present-day active channel down to the lobe complex near 5,000 m of water-depth (Fig. 7). In more detail, the isotopic signature of surface sediments is clearly related to the bathymetry of the station and the distance from the turbidite active channel (Fig. 8). Depending on these two parameters, the OM sedimentation follows two trends. The first trend (dotted arrow on figure 8) shows a more or less constant marine source with heavier isotopic ratios, ranging between -19.5 to $-22.0 \%$, whatever the distance from the coast, the bathymetry and the distance from the active channel. The second trend (solid arrow on figure 8) displays a decrease to lighter isotopic ratios with increasing depth, suggesting an enrichment of terrestrial OM with depth. This enrichment is clearly related to the turbiditic activity along the channel as it starts near 3,000 m of water-depth where the upper fan levees accumulate (Babonneau et al., 2002). Most of the data points defining this trend are located within $25 \mathrm{~km}$ from the active channel. In the terminal lobe zone, near 5,000 m of water-depth, where all material transported by turbidity currents is rapidly deposited (Rabouille et al., this volume), the $\delta^{13}$ Corg values are similar to those of the OM delivered by the Congo River (-27.8\%; Spencer et al., 2012, 2014). This trend is also 
perceptible when examining the HI-values of turbidite-related facies (Fig. 9). It appears that the $\mathrm{HI}$ values of both channel and levee facies are roughly increasing downslope, suggesting a better preservation of terrestrial OM according to depth.

This downslope trends in TOC content and OM composition indicate that particle transport by turbidity currents is the primary mechanism controlling both supply and burial of OM. Indeed, the Congo deep-sea fan is one of the largest turbidite system in the world still affected by turbidite sedimentation during the current interglacial high sea-level (Savoye et al., 2000). Consequently the Congo deep sea fan is prone to dispersal and storage of terrestrial OM in the bathypelagic depths. This is obviously due to the direct connection of the river mouth to the deep ocean by the canyonchannel-levee-lobe system but also to the high proportion of $\mathrm{OM}$ in the suspended material delivered by the Congo River compared to other worldwide rivers.

\section{Conclusion}

In addition to previously published data, one hundred and fifty surface sediments $(<3 \mathrm{~cm}$ and mostly $\leq 1 \mathrm{~cm}$ ) of the Angola basin were geochemically analyzed to determine the quantity and quality of their organic matter content. The resulting dataset (322 stations) shows a better spatial and bathymetric representativeness of the Angola basin. Based on this enhanced dataset, total organic carbon (TOC) content and $\delta^{13}$ Corg maps of the Angola basin were generated using the natural neighbor gridding method of Surfer@ software. The main difference in the resulting maps with previously published ones is the high terrestrial organic matter content observed downslope along the active turbidite channel of the Congo deep sea fan. This is particularly apparent near $5,000 \mathrm{~m}$ of water-depth in the distal part of the fan, where the terminal lobe complex of the presently active turbidite system is developed.

Quantification of organic matter sources, whether continental or marine, in surface sediments of the Angola basin as estimated using carbon isotopic signature of organic matter $\left(\delta^{13} \mathrm{Corg}\right)$ led to determine the proportion of marine and terrestrial sources and allows drawing an organic matter composition map. The isotopic signature of surface sediments is clearly related to both the bathymetry of the station and the distance from the active turbidite channel.

Interpretation of downslope trends in TOC content and organic matter composition points to the particle transport originating from the Congo River by turbidity currents as the primary controlling factor to supply and accumulate organic matter. Finally, the Congo deep sea fan appears a very efficient system to transfer and terrestrial organic matter directly to the bathypelagic depths and store it in sediments. Considering the high sedimentation rates related to the canyon-channel-leveelobe system and the high proportion of TOC, massive amount of organic matter are stored in this abyssal part of the Atlantic Ocean during the present-day high sea-level. Whether organic supply and 


\section{ACCEPTED MANUSCRIPT}

accumulation were different during cold (glacial) low stand periods in this system remains an open question.

\section{Acknowledgements}

We thank Ifremer and Total for providing samples from the Guiness, Zaïango, and Zaïrov campaigns. We are grateful to Ifremer/Genavir captains and crews for the Reprezaï, WACS and Congolobe campaigns onboard the R/V Pourquoi Pas? as well as Karine Olu for leading the WACS campaign. We acknowledge Philippe Noël, Bruno Bombled, Solveig Bourgeois, Sabrina Lucas, Johann Schnyder and Gilles Vétion for their participation in sampling during WACS and Congolobe campaigns. We acknowledge Florence Savignac for analytical help on the Rock-Eval apparatus. The comments of two anonymous reviewers help us to improve this paper. This work was partly funded by the CNRSINSU/Actions Marges program and the ANR grant Congolobe (ANR-11-BS56-0030, 60 2011-2015).

\section{References}

Antoine, D., André, J.-M., Morel, A., 1996. Oceanic primary production; 2. Estimation at global scale from satellite (coastal zone color scanner) chlorophyll. Global Biogeochemical Cycles 10 (1), 5769.

Archer, D.E., 1996. An atlas of the distribution of calcium carbonate in sediments of the deep sea. Global Biogeochemical Cycles 10 (1), 159-174.

Babonneau, N., 2002. Mode de fonctionnement d'un chenal turbiditique méandriforme: Cas du système turbiditique actuel du Zaïre. Thèse de doctorat, Université de Bordeaux I, 308 p.

Babonneau, N., Savoye, B., Cremer, M., Bez, M., 2004. Multiple terraces within the deep incised Zaire valley (ZaïAngo Project): are they confined levees? In: S.A. Lomas and P. Joseph (Editors), Confined Turbidite Systems. Special Publications. Geological Society, London, pp. 91-114.

Babonneau, N., Savoye, B., Cremer, M., Bez, M., 2010. Sedimentary Architecture in Meanders of a Submarine Channel: Detailed Study of the Present Congo Turbidite Channel (Zaiango Project). J. Sed. Res. 80, 852-866.

Babonneau, N., Savoye, B., Cremer, M., Klein, B., 2002. Morphology and architecture of the present canyon and channel system of the Zaire deep-sea fan. Mar. Petrol. Geol. 19, 445-467.

Baudin, F., Disnar, J.R., Aboussou, A., Savignac, F., 2015. Guidelines for Rock-Eval analysis of recent marine sediments. Organic Geochemistry, 86, 71-80. 


\section{ACCEPTED MANUSCRIPT}

Baudin, F., Disnar, J.R., Martinez, P., Dennielou, B., 2010. Distribution of the organic matter in the channel-levees systems of the Congo mud-rich deep sea fan (West Africa). Implication for deep offshore petroleum source rocks and global carbon cycle. Mar. Petrol. Geol. 27, 995-1010.

Baudin, F., Stetten, E., Schnyder, J., Charlier, K., Martinez, P., Dennielou, B., Droz, L., submitted. Origin and distribution of the organic matter in the distal lobe of the Congo deep-sea fan - A Rock-Eval survey. DSRII special publication 'Congolobe'

Berger, W.H., 1989. Global maps of ocean productivity. In: Berger, W.H., Smetacek, V.S., Wefer, G. (Eds.), Productivity of the Ocean: Present and Past. Wiley-Interscience, New York, pp. 429-455.

Berner, R.A., 1982. Burial of organic carbon and pyrite sulphur in the modern ocean: its geochemical and environmental significance. American Journal of Science 282, 451-473.

Bianchi, T.S., Allison, M.A., Cai, W.J., 2014. An introduction to the biogeochemistry of river-coastal systems. In Biogeochemical dynamics at Major River-Coastal Interfaces Linkages with Global Change (eds. T.S. Bianchi, M.A. Allison and W.J. Cai) Cambridge Univ. Press, 3-18.

Bickert, T., Wefer, G., 1996. Late Quaternary deep-water circulation in the South Atlantic: reconstruction from carbonate dissolution and benthic stable isotopes. In: Berger, W.H., Wefer, G., Siedler, G., Webb, D.J. (Eds.), The South Atlantic: Present and Past Circulation. Springer, Berlin, pp. 599-620.

Biscara, L., Mulder, T., Martinez, P., Baudin, F., Etcheber, H., Jouanneau, J.M., Garlan, T., 2011. Transport of terrestrial organic matter in the Ogooué deep sea turbidite system (Gabon). Marine and Petroleum Geology 28, 1061-1072.

Blair, N.E., Aller, R.C., 2012. The fate of terrestrial organic carbon in the marine environment. Annu. Rev. Mar. Sci. 4, 401-423.

Bongo-Passi, G., 1984. Contribution à l'étude lithostratigraphique, minéralogique et géochimique du delta sous-marin profond du fleuve Congo. Unpublished Ph. D. Dissertation [M.S. Thesis], University of Toulouse, 215 p.

Bonnel, C., 2005. Mise en place des lobes distaux dans les systèmes turbiditiques actuels : Analyse comparée des systèmes du Zaïre, Var et Rhône. Thèse de doctorat, Université de Bordeaux I, $275 p$.

Burdige, D.J., 2005. Burial of terrestrial organic matter in marine sediments, a re-assessment. Global Biogeochemical Cycles. 19, 4, GB4011, doi:10.1029/2004GB002368.

Cadée, G.C., 1984. Particulate and dissolved organic carbon and chlorophyll a in the Zaire River, estuary and plume. Neth. J. Sea Res. 17, 426-440.

Cochonat, P., 1993. GUINESS 2 cruise, RV Le Suroît. http://dx.doi.org/10.17600/93000190

Cochonat, P., 1998. ZAIANGO2 cruise, RV L'Atalante. http://dx.doi.org/10.17600/98010110

Cochonat, P., Robin, A., 1992. GUINESS I cruise, RV L'Atalante. http://dx.doi.org/10.17600/92004211 


\section{ACCEPTED MANUSCRIPT}

Cwienk, D.S., 1986. Recent and glacial age organic carbon and biogenic silica accumulation in marine sediments. Master of Science Thesis, University of Rhode Island, 237 pp.

Dagg, M., Benner, R., Lohrenz, S., Lawrence, D., 2004. Transformation of dissolved and particulate materials on continental shelves influenced by large rivers: plume processes. Contin. Shelf Res. $24,833-858$.

Dalibard, M., Popescu, S.M., Maley, J., Baudin, F., Melinte-Dobrinescu, M.C., Pittet, B., Marsset, T., Dennielou, B., Droz, L., Suc, J.P. 2014 - High resolution vegetation history of West Africa during the last 145 ka. Geobios, 47(4), 183-198.

Degens, E.T., Kempe, S., Richey, J.E., 1991. Summary: biogeochemistry of major world rivers in: Degens, E.T., Kempe, S., Richey, J.E. (Eds.), Biogeochemistry of major world rivers. Wiley and sons, Chichester, pp. 323-348.

Droz L., Rigaut F., Cochonat P., Tofani R., 1996. Morphology and recent evolution of the Zaire turbidite system (Gulf of Guinea). Geol. Soc. Am. Bull., 108, 253-269.

Droz, L., Marsset, T., Ondreas, H., Lopez, M., Savoye, B., Spy-Anderson, L., 2003. Architecture of an active mud-rich turbidite system: the Zaire Fan (Congo-Angola margin southeast Atlantic). Results from Zaiango 1 and 2 cruises, 87(7): AAPG Bulletin 87, 1145-1168.

Emelyanov, E.M., Romankevich, E.A., 1979. Geochemistry of the Atlantic Ocean: Organic Carbon and Phosphorous. Nauka, Moscow, 220 pp., in Russian.

Espitalié, J., Deroo, G., Marquis, F. 1985. La pyrolyse Rock-Eval et ses applications. Partie I. Rev. Inst. Fr. Pétrole, 40/5, 563-579.

François, R., Honjo, S., Krishfield, R., Manganini, S., 2002. Factors controlling the flux of organic carbon to the bathypelagic zone of the ocean. Global Biogeochemical Cycles 16. 4, 34-1-34-20

Hedges, J.I., Keil, R.G., 1995. Sedimentary organic-matter preservation an assessment and speculative synthesis. Mar. Chem. 49, 81-115.

Heezen, B.C., Menzies, R.J., Schneider, E.D., Ewing, W.M., Granelli, N.C.L., 1964. Congo Submarine Canyon. AAPG Bulletin 48, 1126-1149.

Inthorn, M., Mohrholz, V., Zabel, M., 2006. Nepheloid layer distribution in the Benguela upwelling area offshore Namibia. Deep-Sea Research Part I-Oceanographic Research Papers, 53, 8, 14231438.

Jahnke, R.A., 1996. The global ocean flux of particulate organic carbon: areal distribution and magnitude. Global Biogeochemical Cycles 10, 71-88.

Jansen, J.H.F., van Weering, T.C.E., Gieles, R., Van Iperen, J., 1984. Middle and Late Quaternary oceanography and climatology of the Zaire-Congo fan and adjacent eastern Angola Basin. Netherlands Journal of Sea Research, 17(2-4): 201-249

Khripounoff, A., 2003. BIOZAIRE 3 cruise, RV L'Atalante. http://dx.doi.org/10.17600/3010120 


\section{ACCEPTED MANUSCRIPT}

Khripounoff, A., Vangriesheim, A., Babonneau, N., Crassous, P., Savoye, B., Dennielou, B., 2003.

Direct observation of intense turbidity current activity in the Zaire submarine valley at $4000 \mathrm{~m}$ water depth. Mar. Geol. 194, 151-158.

Kinga-Mouzeo, M. 1986. Transport particulaire actuel du fleuve Congo et de quelques affluents; enregistrement quaternaire dans l'éventail détritique profond (sédimentologie, minéralogie et géochimie). Unpublished Ph. D. Dissertation [M.S. Thesis], University of Perpignan, 251 p.

Kolla, V., Biscaye, P.E., Hanley, A.F., 1979. Distribution of quartz in late Quaternary Atlantic sediments in relation to climate. Quaternary Research, 11, 2, 261-277.

Lisitzin, A.P., Emelyanov, E.M., Ilyin, A.V., Likoshevitchus, L.S., Senin, Y.M., Svirenko, Y.P., Soldatov, A.V., Shurko, Y.I., 1975. Distribution of bottom sediments in the Atlantic Ocean. In: Lisitzin, A. (Ed.), Sedimentation in the Atlantic Ocean. Kalinigradskaya Pravda, Kaliningrad, p. 323 in Russian.

Marsset, T., Droz, L., 2010. REPREZAI_LEG1 cruise, RV Pourquoi pas ? http://dx.doi.org/10.17600/10030170

Marsset, T., Droz, L., Dennielou, B., Pichon, E., 2009. Cycles in the architecture of the Quaternary Zaire turbidite system: a possible link with climate, in: Kneller, B. (Ed.), External Controls on Deep-Water Depositional Systems. SEPM Special Publication, pp. 89-106.

Migeon, S., Savoye, B., Babonneau, N., Spy-Anderson, F.-L., 2004. Processes of sediment-waves construction along the present Zaire Deep-sea meandering channel: role of meanders and flow stripping. Journal of Sedimentary Research, 74(4): 580-598.

Mollenhauer, G., Schneider, R.R., Jennerjahn, T., Muller, P.J., Wefer, G., 2004. Organic carbon accumulation in the South Atlantic Ocean: its modern, mid-Holocene and last glacial distribution. Glob. Planet. Change 40, 249-266. doi:10.1594/PANGAEA.71218

Müller, P.J., Schneider, R.R., Ruhland, G., 1994. Late Quaternary pCO2 variations in the Angola Current: evidence from organic carbon $\mathrm{d} 13 \mathrm{C}$ and alkenone temperatures. In: Zahn, R., Kaminski, M.A., Labeyrie, L., Pederson, T.F. (Eds.), Carbon Cycling in the Glacial Ocean: Constraints on the Ocean's Role in Global Change. ASI Series. Springer, Berlin, pp. 343-366.

Olu K., 2011. WACS cruise, Pourquoi Pas? R/V, http://dx.doi.org/10.17600/11030010

Perdue, M., Koprivnjak, J.F., 2007. Using the $\mathrm{C} / \mathrm{N}$ ratio to estimate terrigenous inputs of organic matter to aquatic environments. Estuar. Coastal Shelf Sci. 73, 65-72.

Peters, K.E., 1986. Guidelines for evaluating petroleum source rock using programmed pyrolysis. American Association of Petroleum Geologists Bulletin. 70, 318-329.

Picot, M., Droz, L., Marsset, T., Dennielou, B., Bez, M., 2016. Controls on turbidite sedimentation: Insights from a quantitative approach of submarine channel and lobe architecture (Late Quaternary Congo Fan). Mar. Petr. Geol., 72, 423-446. 


\section{ACCEPTED MANUSCRIPT}

Rabouille C., 2011. CONGOLOBE cruise, Pourquoi Pas? R/V, http://dx.doi.org/10.17600/11030170

Rabouille C., Olu K., Baudin F., Khripounoff A., Dennielou B., Arnaud-Haond S., Babonneau N., Bayle C., Beckler J., Bessette S., Bombled B., Bourgeois S., Brandily C., Caprais JC., Cathalot C., Charlier K., Corvaisier R., Croguennec C., Cruaud P., Decker C., Droz L., Gayet N., Godfroy A., Hourdez S., Le Bruchec J., Le Saout J., Lesaout M., Lesongeur F., Martinez P., Mejanelle L., Michalopoulos P., Mouchel O., Noel P., Pastor L., Picot M., Pignet P., Pozzato L., Pruski AM., Rabiller M., Raimonet M., Ragueneau O., Reyss JL., Rodier P., Ruesch B., Ruffine L., Savignac F., Senyarich C., Schnyder J., Sen A., Stetten E., Sun M-Y., Taillefert M., Teixeira S., Tisnerat-Laborde N., Toffin L., Tourolle J., Toussaint F., Vetion G., Jouanneau JM., Bez M., this volume, The Congolobe project, a multidisciplinary study of Congo deep-sea fan lobe complex: Overview of methods, strategies, observations and sampling. Deep-Sea Res. Part II-Top. Stud. Oceanogr., in press

Rabouille, C., Caprais, J.C., Lansard, B., Crassous, P., Dedieu, K., Reyss, J.L., Khripounoff, A., 2009. Organic matter budget in the Southeast Atlantic continental margin close to the Congo Canyon: In situ measurements of sediment oxygen consumption. Deep-Sea Res. Part II-Top. Stud. Oceanogr. 56, 2223-2238

Reid, J.L., 1996. On the circulation of the South Atlantic Ocean. In: Wefer, G., Berger, W.H., Siedler, G., Webb, D.J. (Eds.), The South Atlantic: Present and Past Circulation. Springer, Berlin, pp. 1344.

Romankevich, E.A., 1994. Biogeochemistry of the Boundary Zones in the Atlantic Ocean. Nauka, Moscow, 400 pp.

Rühlemann, C., Müller, P.J., Schneider, R.R., 1999. Organic carbon and carbonate as paleoproductivity proxies: examples from high and low productivity areas of the Tropical Atlantic. In: Fischer, G., Wefer, G. (Eds.), Use of Proxies in Paleoceanography: Examples from the South Atlantic. Springer, Berlin, pp. 315-344.

Savoye, B., 1998. ZAIANGO1 cruise, RV L'Atalante. http://dx.doi.org/10.17600/98010100

Savoye, B. and Ondréas, H., 2000. ZAIANGOROV cruise, RV L'Atalante. http://dx.doi.org/10.17600/10100

Savoye, B., Babonneau, N., Dennielou, B., Bez, M., 2009. Geological overview of the Angola-Congo margin, the Congo deep-sea fan and its submarine valleys. Deep-Sea Res. Part II-Top. Stud. Oceanogr. 56, 2169.

Savoye, B., Cochonat, P., Apprioual, R., Bain, O., Baltzer, A., Bellec, V., Beuzart, P., Bourillet, J., Cagna, R., Cremer, M., Crusson, A., Dennielou, B., Diebler, D., Droz, L., Ennes, J., Floch, G., Foucher, J., Guiomar, M., Harmegnies, F., Kerbrat, R., Klein, B., Khun, H., Landure, J., Lasnier, C., Le Drezen, E., Le Formal, J., Lopez, M., Loubrieu, B., Marsset, T., Migeon, S., Normand, A., Nouze, H., Ondreas, H., Pelleau, P., Saget, P., Seranne, M., Sibuet, J.C., Tofani, R., Voisset, M., 2000. 


\section{ACCEPTED MANUSCRIPT}

Structure et évolution récente de l'éventail turbiditique du Zaïre: Premiers résultats scientifiques des missions d'exploration ZaiAngo 1 and 2 (Marge Congo-Angola). C. R. Acad. Sci. Paris 311, 211-220.

Schlünz, B., Schneider, R.R., 2000. Transport of riverine organic carbon to the oceans: implications for the carbon cycle. Geologische Rundschau 88, 599-606.

Schneider, R.R., Price, B., Müller, P.J., Kroon, D., Alexander, I., 1997. Monsoon related variations in Zaire (Congo) sediment load and influence of fluvial silicate supply on marine productivity in the east equatorial Atlantic during the last 200,000 years. Paleoceanography 12 (3), 463-481.

Seiter, K., Hensen, C., Schroter, E., Zabel, M., 2004. Organic carbon content in surface sediments defining regional provinces. Deep-Sea Research Part I-Oceanographic Research Papers, 51, 12, 2001-2026.

Sibuet, M., 2001a. BIOZAIRE 1 cruise, RV L'Atalante. http://dx.doi.org/10.17600/1010010

Sibuet, M., 2001b. BIOZAIRE 2 cruise, RV L'Atalante. http://dx.doi.org/10.17600/1010130

Spencer, R.G.M., Hernes, P.J., Aufdenkampe, A.K., Baker, A., Gulliver, P., Stubbins, A., Aiken, G.R., Dyda, R.Y., Butler, K.D., Mwamba, V.L., Mangangu, A.M., Wabakanghanzi, J.N., Six, J., 2012. An initial investigation into the organic matter biogeochemistry of the Congo River. Geochim. Cosmochim. Acta 84, 614-627.

Spencer, R.G.M., Stubbins, A., Gaillardet, J., 2014. Geochemistry of the Congo River, estuary and plume. In Biogeochemical dynamics at Major River-Coastal Interfaces Linkages with Global Change (eds. T. S. Bianchi., M. A. Allison. and W. J. Cai). Cambridge Univ. Press, Cambridge. pp. 3-18.

Stetten, E., Baudin, F., Reyss, J.L., Martinez, P., Charlier, K., Schnyder, J., Rabouille, C., Dennielou, B., Coston-Guarini, J., Pruski, A., 2015. Organic matter characterization and distribution in sediments of the terminal lobes of the Congo deep-sea fan: evidence for the direct influence of the Congo River. Mar. Geol. 369, 182-195.

Tissot, B.P., Welte, D.H., 1984. Petroleum Formation and Occurrence. Springer, Berlin, 699 p.

Treignier, C. 2005. Apports en matière organique marine et terrigène sur la marge équatoriale ouest africaine : rôle joué par le canyon sous-marin du Zaïre. Approche par les biomarqueurs lipidiques. Thèse UPMC, $131 \mathrm{p}$.

Treignier, C., Derenne, S., Saliot, A., 2006. Terrestrial and marine $\mathrm{n}$-alcohol inputs and degradation processes relating to a sudden turbidity current in the Zaire canyon. Org. Geochem. 37, 11701184.

Vangriesheim, A., Khripounoff, A., Crassous, P., 2009. Turbidity events observed in situ along the Congo submarine channel. Deep-Sea Res. Part II-Top. Stud. Oceanogr. 56, 2208-2222. 


\section{ACCEPTED MANUSCRIPT}

Voituriez, B., Herbland, A., 1981. Primary production in the tropical Atlantic Ocean mapped from oxygen values of Equalant 1 and 2 (1963). Bull. Mar. Sci. 31, 853-863.

Wagner, T., Zabel, M., Dupont, L., Holtvoeth, J., Schubert, C.J., 2004. Terrigenous signals in sediments of the low latitude Atlantic implications for environmental variations during the late Quarternary: Part 1: Organic carbon. In Wefer, G., Mulitza, S., Ratmeyer, V. (eds), South Atlantic in the late Quaternary: reconstruction of material budgets and current systems. Springer, 295322.

Weijer, J.W.H., Schouten, S., Schefuss, E., Schneider, R.R., Sinninghe Damsté, J.S., 2009. Disentangling marine, soil and plant organic carbon contributions to continental margin sediments: a multiproxy approach in a 20,000 year sediment record from Congo deep-sea fan. Geochem. Cosmochim. Acta 73, 119-132.

Westerhausen, L., Poynter, J., Eglinton, G., Erlenkeuser, H., Sarnthein, M., 1993. Marine and terrigenous origin of organic matter in modern sediments of the equatorial East Atlantic: the $\delta^{13} \mathrm{C}$ and molecular record. Deep-Sea Research I 40 (5), 1087- 1121.

Fig. 1 - 3D view of the bathymetry of Angola basin in the southeastern Atlantic Ocean with surface and bottom currents. The white line corresponds to the present-day active channel of the Congo deep sea fan and the red rectangle encloses the terminal lobe complex.

Fig. 2 - Bathymetric distribution of the sediments related to the Congo deep sea fan (in \% of a total surface of $\sim 300,000 \mathrm{~km}^{2}$ ) compared to the bathymetric distribution of the cores located between $3^{\circ}$ and $9^{\circ} \mathrm{S}$ reported in both previous studies (in \% of 94 stations) and this study (in \% of 251 stations). To this respect, our dataset presents a better representativeness than those used in previous studies. Nevertheless, shallow depths $(<1,000 \mathrm{~m})$ are still slightly over-represented compared to abyssal depths $(>3,000 \mathrm{~m})$.

Fig. 3a - Map of the total organic carbon (TOC) content (wt \%) in surface sediments $(<3 \mathrm{~cm}$ and in most cases $\leq 1 \mathrm{~cm}$ ) of Angola basin according to available dataset before the present study. Sample locations (172 stations, red dots) are indicated by the red dots. Areas blanked during the gridding procedure due to insufficient spatial resolution are left white. Sediments related to Congo deep sea fan appeared moderately enriched in TOC and the lobe zone showed similar TOC than surrounding pelagic environments. $3 b$ - Map of the total organic carbon (TOC) content (wt \%) in surface sediments $(<3 \mathrm{~cm})$ of the Angola basin, drawn using 322 stations (the 150 additional stations correspond to black dots). Surface sediments related to the Congo deep sea fan are significantly enriched in TOC and the lobe zone shows the highest values. 


\section{ACCEPTED MANUSCRIPT}

Fig. 4 - Frequency distribution of TOC \% in surface sediments $(<3 \mathrm{~cm}$ ) of the Angola basin (322 stations) according to bathymetric interval. As expected on passive margins influenced by upwelling systems, a significant enrichment in organic matter is noticed between 200 and 1,000 of water-depth in the upper slope area. More interesting is the second enrichment at abyssal depths (from 4,000 to $5,000 \mathrm{~m}$ and deeper) in the Angola basin which is related to the Congo turbidite system. $60 \%$ of the studied stations (105 data points) in the range of 4,000-5,000 m water-depth display TOC contents higher than $2 \%$ and some surface sediment samples may contain up to $5 \%$.

Fig. 5 - Organic matter type in surface sediments $(<3 \mathrm{~cm})$ of the Angola basin as defined by the cross-plot of TOC and S2 Rock-Eval parameters.

Fig. 6 - Frequency distribution of the $\delta^{13} \mathrm{C}_{\text {org }}$ values (in \% V-PDB) in surface sediments $(<3 \mathrm{~cm}$ ) of the Angola basin (159 stations). A bimodal distribution is obvious with a first mode around $-22 \%$ suggesting a dominance of marine phytoplanktonic organic matter and the second around -26\%o implying a dominance of C3 higher-plants to the organic matter preserved in marine sediments.

Fig. 7 - Carbon isotope ratio $\left(\delta^{13} C_{\text {org }}\right.$ in \%o V-PDB) of organic matter in surface sediments $(<3 \mathrm{~cm})$ of the Angola basin (159 stations). Areas blanked during the gridding procedure due to insufficient spatial resolution are left white. The terrestrial organic matter (lowest C-isotope ratios) is clearly distributed along the present-day active channel down to the lobe complex near 5,000 m of waterdepth.

Fig. 8 - Distribution of the $\delta^{13} C_{\text {org }}$ (in \%o V-PDB) in surface sediments $(<3 \mathrm{~cm}$ ) of the Angola basin according to the bathymetry of the station and the distance from the turbidite active channel. Two trends are obvious: a more or less constant marine source with heavier isotopic ratios whatever the distance from the coast and the bathymetry (dotted arrow) and an enrichment of terrestrial organic matter having a lighter isotopic ratios with increasing depth (solid arrow). This enrichment is clearly related to the turbiditic activity along the channel and starts between 2,000 and 3,000 m of waterdepth where the upper fan levees accumulate. Note that the lobe zone, near 5,000 $\mathrm{m}$ of waterdepth, displays similar $\delta^{13} C_{\text {org }}$ values than the organic matter delivered to the Atlantic Ocean by the Congo River (black star).

Fig. 9 - Distribution of hydrogen index $(\mathrm{HI})$ values in surface sediments $(<3 \mathrm{~cm})$ along the turbite system of the Congo deep sea fan according to the sedimentary environment (channel, levee, lobe) and the depositional depth.

Table 1 - Location (Lat., Long., and water-depth) of the studied core tops recovered during different cruises operated by Ifremer. Several types of cores were studied: GC: gravity core, MTB: multitube, ROV CT: remotely operated vehicle core-tube. Bulk geochemical data for each core tops are the followings: TOC: total organic carbon content (in wt \%), C:N: carbon/nitrogen atomic ratio of the 


\section{ACCEPTED MANUSCRIPT}

organic matter, $\delta^{13} \mathrm{C}_{\text {org }}$ : carbon isotopic ratio of the organic matter fraction (in \%o V-PDB), HI: hydrogen index provided by Rock-Eval pyrolysis (in mg HC.g ${ }^{-1} \mathrm{TOC}$ ).

\begin{tabular}{|c|c|c|c|c|c|c|c|c|c|c|}
\hline Leg & Station & $\begin{array}{l}\text { Core } \\
\text { type }\end{array}$ & $\begin{array}{c}\text { Latitud } \\
\mathrm{e}\end{array}$ & $\begin{array}{l}\text { Longitud } \\
\mathrm{e}\end{array}$ & $\begin{array}{c}\text { Water } \\
- \\
\text { depth } \\
{[\mathrm{m}]}\end{array}$ & $\begin{array}{c}\text { Interva } \\
\text { I } \\
\text { sample } \\
\mathrm{d}[\mathrm{cm}]\end{array}$ & $\begin{array}{c}\text { Cor } \\
\text { g } \\
{[\%]}\end{array}$ & $\begin{array}{c}\mathrm{C} / \mathrm{N} \\
\text { [atom] }\end{array}$ & $\begin{array}{l}\delta^{13} \mathrm{C}_{o r} \\
\mathrm{~g}[\% \circ]\end{array}$ & $\begin{array}{c}\mathrm{HI} \\
{[\mathrm{mg} / \mathrm{g}} \\
]\end{array}$ \\
\hline \multicolumn{11}{|c|}{ Congolobe } \\
\hline & & & - & & & & 2.9 & & & \\
\hline \multirow{2}{*}{\multicolumn{2}{|c|}{ COL-A-CSO1 }} & GC & 6.4629 & 6.0320 & -4755 & $0-1$ & 8 & & & 138 \\
\hline & & & - & & & & 2.7 & & & \\
\hline \multirow{2}{*}{\multicolumn{2}{|c|}{ COL-A-MTB02 }} & MTB & 6.4599 & 6.0347 & -4759 & $0-0.5$ & 1 & 14.5 & -25.7 & 134 \\
\hline & & & - & & & & 2.8 & & & \\
\hline \multirow{2}{*}{\multicolumn{2}{|c|}{ COL-A-MTB03 }} & МTB & 6.4702 & 6.0369 & -4764 & $0-0.5$ & 5 & 15.9 & -26.3 & 146 \\
\hline & & & . & & & & 2.9 & & & \\
\hline \multirow{2}{*}{\multicolumn{2}{|c|}{ COL-B-CSO7 }} & $\mathrm{GC}$ & 6.4268 & 5.8262 & -4822 & $0-1$ & 7 & & & 144 \\
\hline & & & - & & & & 2.7 & & & \\
\hline \multicolumn{2}{|r|}{ COL-B-MTB12 } & MTB & 6.4269 & 5.8264 & -4823 & $0-0.5$ & 7 & 15.3 & -25.6 & 180 \\
\hline \multirow{2}{*}{\multicolumn{2}{|c|}{ COL-C-CSO4 }} & GC & 6.6603 & 5.4695 & -4949 & $0-1$ & 5 & & & 145 \\
\hline & & & - & & & & 4.2 & & & \\
\hline \multirow{2}{*}{\multicolumn{2}{|c|}{ COL-C-CSO6 }} & GC & 6.6992 & 5.4888 & -4954 & $0-1$ & 6 & 16.9 & -26.5 & 152 \\
\hline & & & - & & & & 3.5 & & & \\
\hline \multirow{2}{*}{\multicolumn{2}{|c|}{ COL-C-MTB011 }} & MTB & 6.6991 & 5.4888 & -4961 & $0-0.5$ & 0 & 14.9 & -26.7 & 141 \\
\hline & & & & & 8 & & 2.8 & & & \\
\hline \multirow{2}{*}{\multicolumn{2}{|c|}{ COL-C-MTB06 }} & MTB & 6.6711 & 5.4733 & -4951 & $0-0.5$ & 7 & 14.6 & -26.3 & 139 \\
\hline & & ROV & - & & 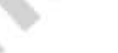 & & 5.4 & & & \\
\hline \multirow{2}{*}{\multicolumn{2}{|c|}{ COL-C-PL490-CT03 }} & $\mathrm{CT}$ & 6.6901 & 5.4797 & -4947 & $0-0.5$ & 2 & & & 160 \\
\hline & & ROV & - & & & & 5.0 & & & \\
\hline \multirow{2}{*}{\multicolumn{2}{|c|}{ COL-C-PL490-CT05 }} & CT & 6.6901 & 5.4797 & -4947 & $0-0.5$ & 3 & & & 156 \\
\hline & & ROV & -2 & & & & 4.7 & & & \\
\hline \multirow{2}{*}{\multicolumn{2}{|c|}{ COL-C-PL490-CT13 }} & $\mathrm{CT}$ & 6.6825 & 5.4819 & -4844 & $0-0.5$ & 0 & & & 107 \\
\hline & & ROV & - & & & & 4.9 & & & \\
\hline \multirow{2}{*}{\multicolumn{2}{|c|}{ COL-C-PL490-CT15 }} & CT & 6.6826 & 5.4822 & -4844 & $0-0.5$ & 3 & & & 148 \\
\hline & & ROV & - & & & & 3.5 & & & \\
\hline \multirow{2}{*}{\multicolumn{2}{|c|}{ COL-C-PL491-CT01 }} & CT & 6.7014 & 5.4882 & -4946 & $0-0.5$ & 3 & & & 127 \\
\hline & & ROV & - & & & & 3.7 & & & \\
\hline \multirow{2}{*}{\multicolumn{2}{|c|}{ COL-C-PL491-CT05 }} & $\mathrm{CT}$ & 6.7014 & 5.4882 & -4946 & $0-0.5$ & 8 & & & 150 \\
\hline & & ROV & - & & & & 4.1 & & & \\
\hline \multirow{2}{*}{\multicolumn{2}{|c|}{ COL-C-PL491-CT14 }} & CT & 6.7016 & 5.4884 & -4846 & $0-0.5$ & 6 & & & 137 \\
\hline & & & - & & & & 1.7 & & & \\
\hline \multirow{2}{*}{\multicolumn{2}{|c|}{ COL-E-MTB14 }} & MTB & 6.0982 & 5.9081 & -4750 & $0-0.5$ & 2 & 11.4 & -23.1 & 110 \\
\hline & & & & & & & 3.2 & & & \\
\hline \multirow{2}{*}{\multicolumn{2}{|c|}{ COL-F-CSO3 }} & GC & 6.5821 & 5.6937 & -4866 & $0-1$ & 2 & & & 120 \\
\hline & & & - & & & & 2.8 & & & \\
\hline & COL-F-MTB05 & MTB & 6.5806 & 5.6911 & -4864 & $0-0.5$ & 2 & 15.4 & -25.7 & 179 \\
\hline \multicolumn{11}{|c|}{ Guiness } \\
\hline & & & - & & & & 3.5 & & & \\
\hline & KG2C05 & GC & 5.2850 & 11.4152 & -685 & $0-1$ & 2 & 11.0 & -22.4 & 166 \\
\hline & KG2G06 & GC & - & 8.5400 & -465 & $0-1$ & 0.9 & & -23.2 & 126 \\
\hline
\end{tabular}




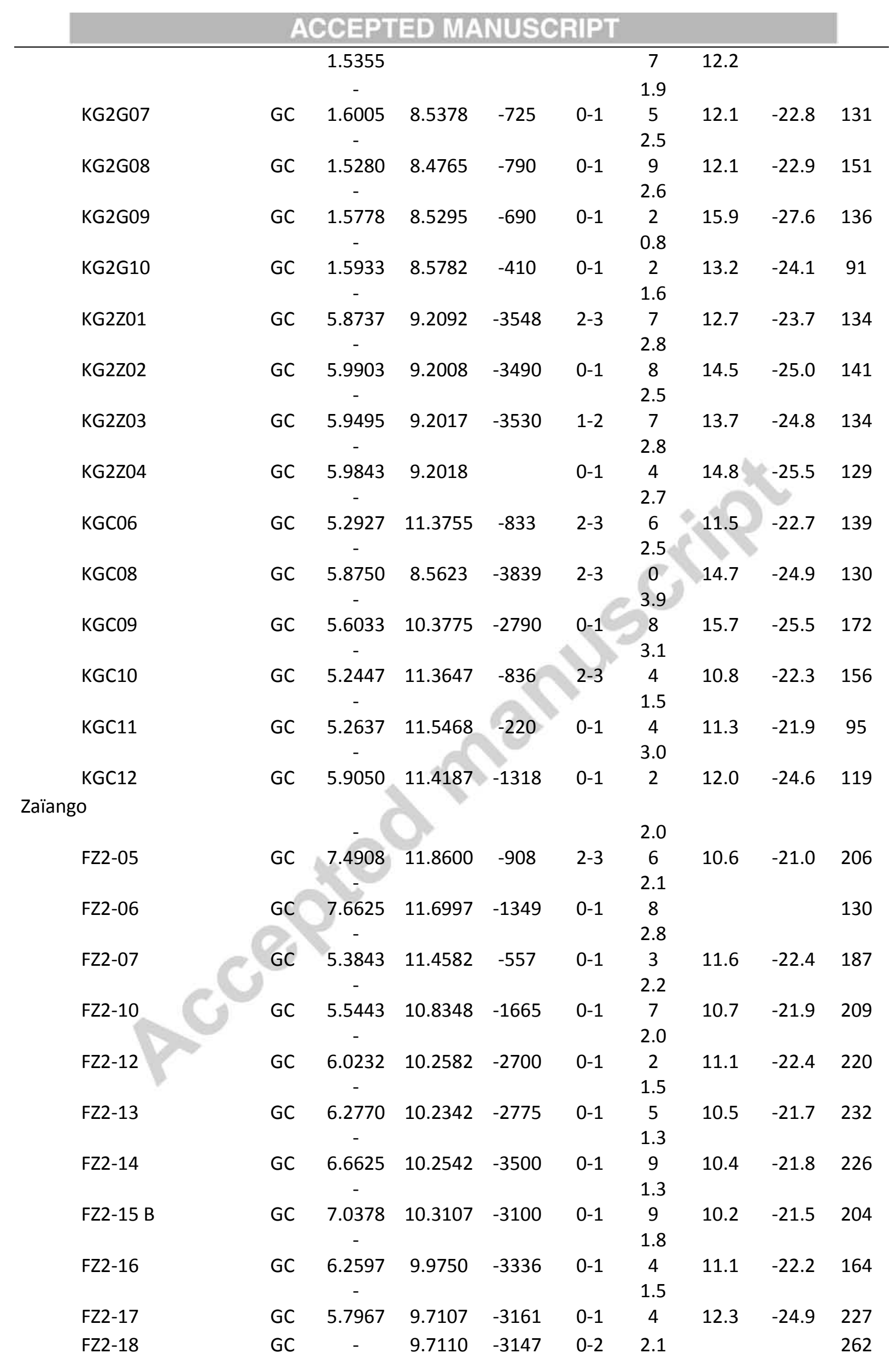




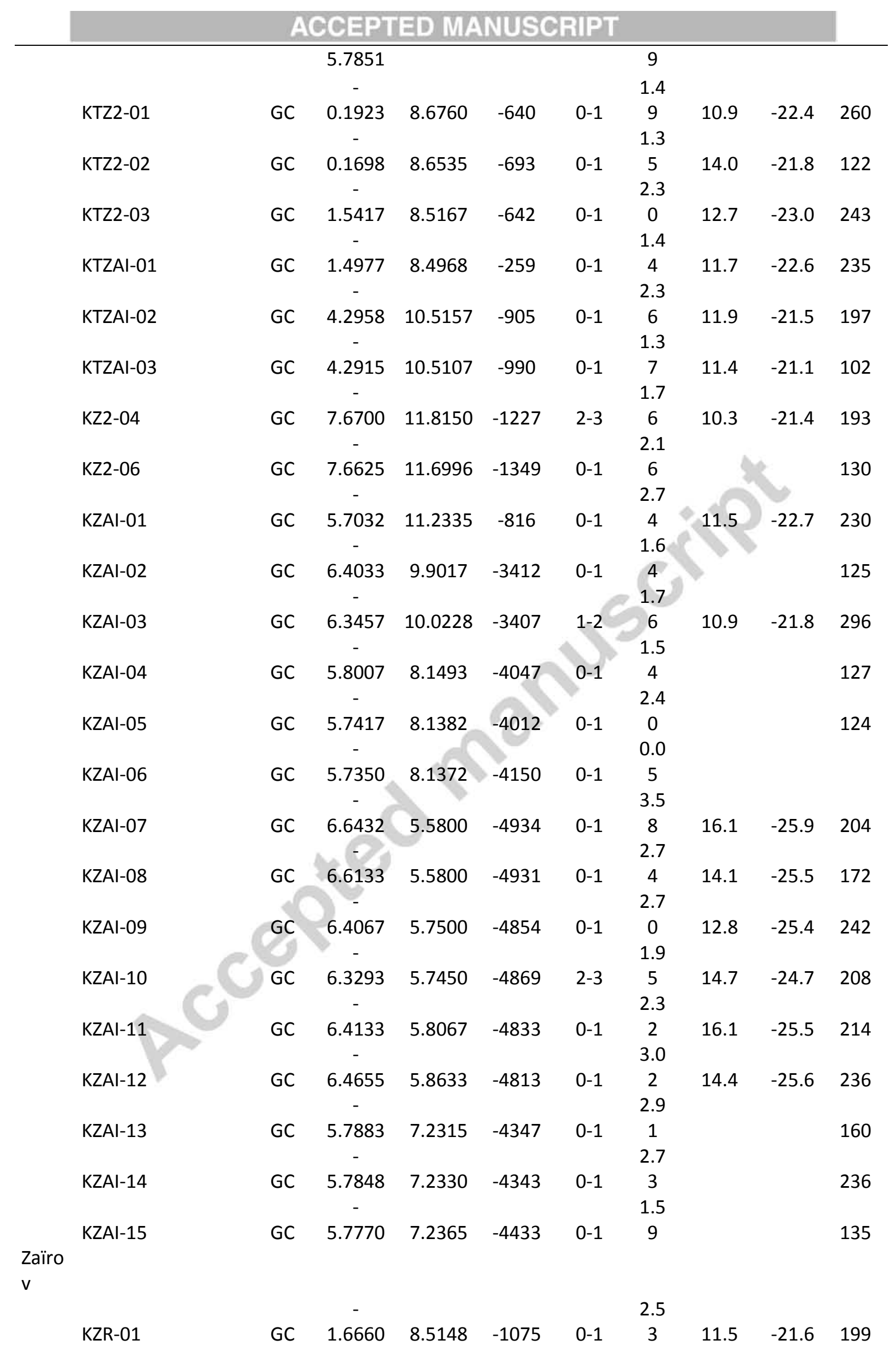




\begin{tabular}{|c|c|c|c|c|c|c|c|c|c|}
\hline KZR-02 & GC & $\begin{array}{c}5.8345 \\
-\end{array}$ & 6.3260 & -4667 & $0-2$ & $\begin{array}{c}0 \\
4.1\end{array}$ & & & 103 \\
\hline KZR-03 & $\mathrm{GC}$ & $\begin{array}{c}6.7573 \\
-\end{array}$ & 5.2935 & -5003 & $0-1$ & $\begin{array}{c}9 \\
4.7\end{array}$ & 15.5 & -26.2 & 227 \\
\hline KZR-04 & $\mathrm{GC}$ & $\begin{array}{c}6.7453 \\
-\end{array}$ & 5.3167 & -5001 & $0-1$ & $\begin{array}{c}8 \\
3.4\end{array}$ & 16.5 & -26.1 & 173 \\
\hline KZR-05 & $\mathrm{GC}$ & $\begin{array}{c}6.7388 \\
-\end{array}$ & 5.3265 & -4978 & $0-1$ & $\begin{array}{c}4 \\
3.9\end{array}$ & 15.9 & -26.2 & 208 \\
\hline KZR-06 & $\mathrm{GC}$ & $\begin{array}{c}6.6952 \\
-\end{array}$ & 5.4852 & -4942 & $0-1$ & $\begin{array}{c}0 \\
1.5\end{array}$ & 15.3 & -26.0 & 177 \\
\hline KZR-07 & $\mathrm{GC}$ & $\begin{array}{c}6.6767 \\
-\end{array}$ & 5.4747 & -4937 & $0-1$ & $\begin{array}{c}1 \\
3.6\end{array}$ & 17.9 & -25.9 & 187 \\
\hline KZR-08 & $\mathrm{GC}$ & $\begin{array}{c}6.4847 \\
-\end{array}$ & 5.4623 & -4933 & $0-1$ & $\begin{array}{c}4 \\
3.8\end{array}$ & 16.7 & -25.8 & 183 \\
\hline KZR-09 & GC & $\begin{array}{c}6.4617 \\
-\end{array}$ & 5.5767 & -4872 & $0-1$ & $\begin{array}{c}2 \\
2.9\end{array}$ & 17.0 & -26.0 & 242 \\
\hline KZR-10 & $\mathrm{GC}$ & $\begin{array}{c}6.4617 \\
-\end{array}$ & 5.6982 & -4835 & $0-1$ & $\begin{array}{c}9 \\
0.0\end{array}$ & 15.1 & -25.9 & 194 \\
\hline KZR-11 & GC & $\begin{array}{c}6.4670 \\
-\end{array}$ & 6.0362 & -4779 & $0-1$ & $\begin{array}{c}5 \\
2.6\end{array}$ & & & \\
\hline KZR-12 & GC & $\begin{array}{c}6.4827 \\
-\end{array}$ & 6.0392 & -4737 & $0-1$ & $\begin{array}{c}9 \\
3.7\end{array}$ & 14.4 & -25.9 & 169 \\
\hline KZR-13 & GC & $\begin{array}{c}5.9168 \\
-\end{array}$ & 6.6783 & -4496 & & $\begin{array}{c}5 \\
3.3\end{array}$ & 15.6 & -26.4 & 200 \\
\hline KZR-14 & GC & $\begin{array}{c}5.9167 \\
-\end{array}$ & 6.7500 & -4445 & $0-1$ & $\begin{array}{c}4 \\
0.6\end{array}$ & 16.0 & -25.6 & 195 \\
\hline KZR-15 & GC & $\begin{array}{c}5.9177 \\
-\end{array}$ & 6.7587 & -4525 & $0-1$ & $\begin{array}{c}4 \\
0.9\end{array}$ & 24.0 & -26.6 & 123 \\
\hline KZR-16 & GC & $\begin{array}{c}5.6517 \\
-\end{array}$ & 7.6167 & -4211 & $0-2$ & $\begin{array}{c}3 \\
3.2\end{array}$ & & & 112 \\
\hline KZR-17 & $\mathrm{GC}$ & 5.9812 & 9.2082 & -3526 & $2-3$ & 2 & 15.6 & -25.9 & 200 \\
\hline KZR-18 & GC & $\begin{array}{c}5.9730 \\
-\end{array}$ & 9.2117 & -3577 & $2-3$ & 0.1 & 15.6 & -25.7 & 210 \\
\hline KZR-19 & GC & $\begin{array}{c}5.9650 \\
-\end{array}$ & 9.2145 & -3699 & $0-1$ & $\begin{array}{c}0 \\
0.0\end{array}$ & & & 100 \\
\hline KZR-21 & $\mathrm{GC}$ & $\begin{array}{c}5.9637 \\
-\end{array}$ & 9.2155 & -3709 & $2-3$ & $\begin{array}{c}7 \\
2.5\end{array}$ & & & \\
\hline KZR-22 & $\mathrm{GC}$ & $\begin{array}{c}5.9682 \\
-\end{array}$ & 9.2133 & -3660 & $0-1$ & $\begin{array}{c}0 \\
2.8\end{array}$ & 15.2 & -25.8 & 186 \\
\hline KZR-23 & $\mathrm{GC}$ & $\begin{array}{c}5.6765 \\
-\end{array}$ & 10.6400 & -2187 & $2-3$ & $\begin{array}{c}9 \\
3.3\end{array}$ & 13.2 & -24.4 & 149 \\
\hline KZR-24 & $\mathrm{GC}$ & $\begin{array}{c}5.6693 \\
-\end{array}$ & 10.6568 & -2375 & $2-3$ & $\begin{array}{c}2 \\
2.9\end{array}$ & 15.0 & -25.6 & 159 \\
\hline KZR-25 & $\mathrm{GC}$ & $\begin{array}{c}5.3810 \\
-\end{array}$ & 11.4463 & -597 & $0-1$ & $\begin{array}{c}5 \\
2.6\end{array}$ & 12.0 & -23.6 & 152 \\
\hline KZR-26 & $\mathrm{GC}$ & $\begin{array}{c}5.3850 \\
-\end{array}$ & 11.4705 & -502 & $0-1$ & $\begin{array}{c}5 \\
3.1\end{array}$ & 10.9 & -22.4 & 136 \\
\hline KZR-27 & $\mathrm{GC}$ & $\begin{array}{c}5.3823 \\
-\end{array}$ & 11.4575 & -550 & $0-1$ & $\begin{array}{c}6 \\
2.0\end{array}$ & 11.6 & -22.9 & 145 \\
\hline KZR-29 & $\mathrm{GC}$ & 5.4598 & 10.9635 & -1496 & $2-3$ & 5 & 11.4 & -23.4 & 125 \\
\hline
\end{tabular}




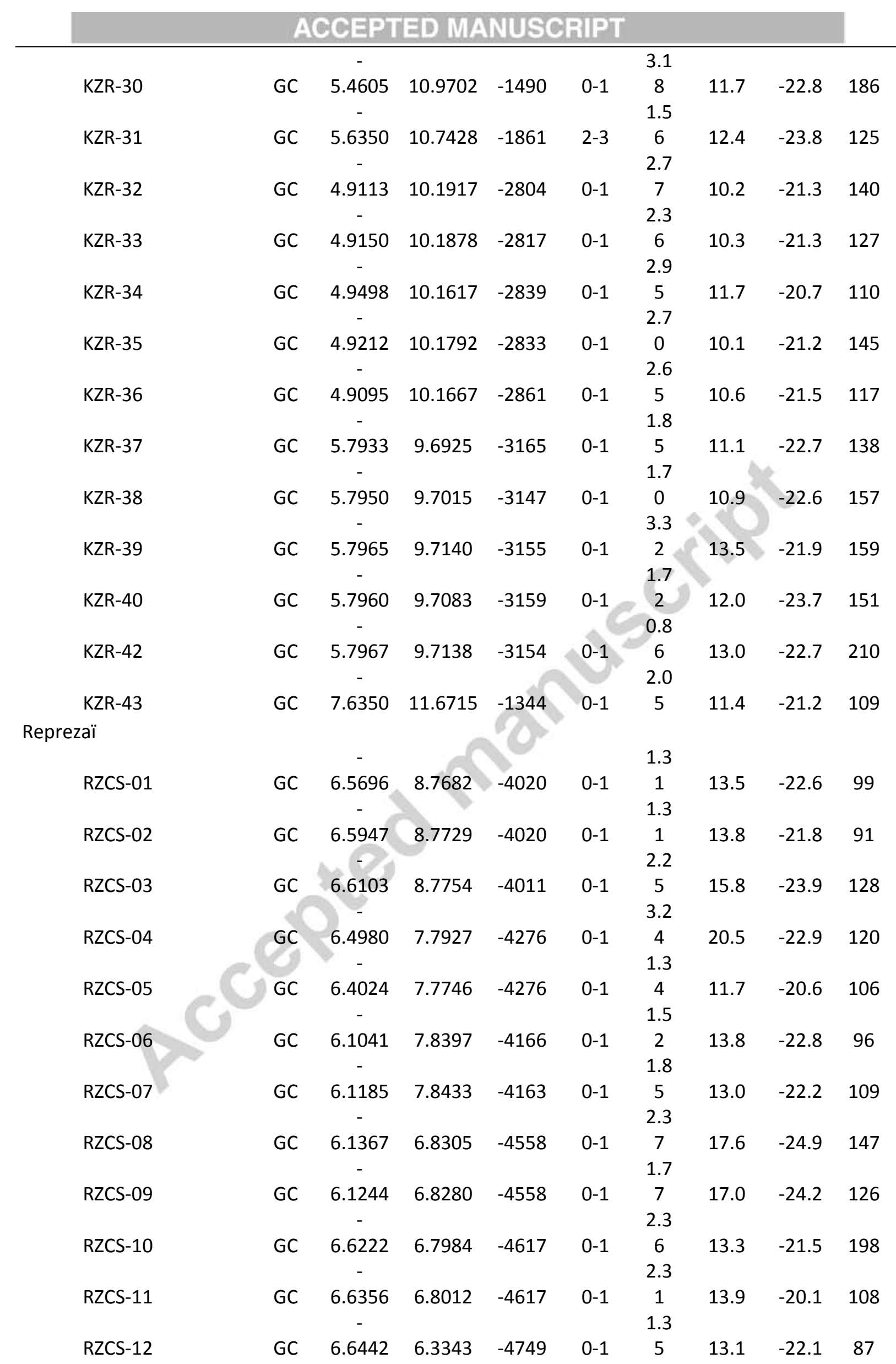




\begin{tabular}{|c|c|c|c|c|c|c|c|c|c|c|}
\hline & \multicolumn{9}{|c|}{ ACCEPTED MANUSCRIPT } & \multirow{3}{*}{215} \\
\hline & \multirow[b]{2}{*}{ RZCS-13 } & \multicolumn{3}{|c|}{-} & \multicolumn{5}{|c|}{1.6} & \\
\hline & & $\mathrm{GC}$ & 6.7284 & 6.2219 & -4790 & $0-1$ & 4 & 13.4 & -21.7 & \\
\hline & & & - & & & & 1.6 & & & \\
\hline & RZCS-14 & $\mathrm{GC}$ & 6.7525 & 6.2267 & -4783 & $0-1$ & 9 & 11.4 & -20.8 & 118 \\
\hline & & & - & & & & 0.8 & & & \\
\hline & RZCS-15 & $\mathrm{GC}$ & 6.9739 & 5.6601 & -4973 & $0-1$ & 5 & 13.0 & -19.8 & 131 \\
\hline & & & - & & & & 4.8 & & & \\
\hline & RZCS-16 & $\mathrm{GC}$ & 7.9079 & 6.2411 & -4925 & $0-1$ & 7 & 22.2 & -23.8 & 194 \\
\hline & & & - & & & & 1.5 & & & \\
\hline & RZCS-17 & $\mathrm{GC}$ & 7.1037 & 6.8859 & -4592 & $0-1$ & 0 & 14.9 & -22.0 & 73 \\
\hline & & & - & & & & 4.2 & & & \\
\hline & RZCS-18 & GC & 7.3099 & 6.0056 & -4897 & $0-1$ & 7 & 23.8 & -24.6 & 145 \\
\hline & & & - & & & & 2.8 & & & \\
\hline & RZCS-19 & $\mathrm{GC}$ & 8.3169 & 5.4670 & -5175 & $0-1$ & 8 & 21.2 & -23.9 & 124 \\
\hline & & & - & & & & 2.1 & & & \\
\hline & RZCS-20 & $\mathrm{GC}$ & 7.8018 & 5.5170 & -5064 & $0-1$ & 4 & 13.6 & -21.1 & 112 \\
\hline & & & - & & & & 1.7 & & & \\
\hline & RZCS-21 & $\mathrm{GC}$ & 7.3873 & 4.6301 & -5178 & $0-1$ & 8 & 11.2 & -20.8 & 143 \\
\hline & & & - & & & & 1.0 & & & \\
\hline & RZCS-22 & $\mathrm{GC}$ & 6.7502 & 5.1984 & -5009 & $0-1$ & 3 & 12.3 & -20.6 & 189 \\
\hline & & & - & & & & 1.2 & & & \\
\hline & RZCS-23 & GC & 6.5111 & 5.1044 & -5016 & $0-1$ & 1 & 13.5 & -22.7 & 129 \\
\hline & & & - & & & & 2.7 & & & \\
\hline & RZCS-24 & GC & 6.5141 & 4.9893 & -5056 & $0-1$ & 2 & 16.9 & -25.8 & 136 \\
\hline & & & - & & & & 3.0 & & & \\
\hline & RZCS-25 & GC & 5.7953 & 5.7307 & -4843 & $0-1$ & 7 & 18.7 & -26.5 & 145 \\
\hline & & & - & & & & 2.0 & & & \\
\hline & RZCS-26 & GC & 5.5647 & 5.1177 & -4972 & $0-1$ & 3 & 19.0 & -25.6 & 96 \\
\hline WAC & & & & & & & & & & \\
\hline $\mathrm{S}$ & & & & & & & & & & \\
\hline & & & - & & & & 2.4 & & & \\
\hline & WACS-A-MTB03 & MTB & 6.4543 & 6.0323 & -4884 & $0-0.5$ & 4 & 17.0 & -26.9 & 158 \\
\hline & WACS-A-PL435- & ROV & - & & & & 2.7 & & & \\
\hline & СТ08 & $\mathrm{CT}$ & 6.4484 & 6.0321 & -4750 & $0-0.5$ & 9 & 17.5 & -27.7 & 173 \\
\hline & & & . & & & & 3.3 & & & \\
\hline & WACS-C-MTB04 & MTB & 6.6877 & 5.4832 & -4950 & $0-0.5$ & 1 & 19.6 & -27.0 & 155 \\
\hline & WACS-C-PL436- & ROV & - & & & & 2.7 & & & \\
\hline & СT11 & $\mathrm{CT}$ & 6.7033 & 5.4886 & -4946 & $0-0.5$ & 7 & 14.0 & -28.0 & 150 \\
\hline & WACS-C-PL437- & ROV & - & & & & 3.0 & & & \\
\hline & СТ02 & $\mathrm{CT}$ & 6.7014 & 5.4883 & -4946 & $0-0.5$ & 1 & 18.7 & -27.3 & 181 \\
\hline & WACS-C-PL437- & ROV & - & & & & 2.9 & & & \\
\hline & СТ08 & $\mathrm{CT}$ & 6.7013 & 5.4881 & -4946 & $0-0.5$ & 2 & 17.3 & -27.0 & 166 \\
\hline & & & - & & & & 3.9 & & & \\
\hline & WACS-CSO6 & GC & 6.7394 & 5.3266 & -4996 & $0-1$ & 3 & & & 158 \\
\hline & WACS-D-PL438- & ROV & - & & & & 3.3 & & & \\
\hline & СТ02 & $\mathrm{CT}$ & 6.7925 & 5.2132 & -5028 & $0-0.5$ & 2 & 19.3 & -26.2 & 170 \\
\hline & WACS-D-PL438- & ROV & - & & & & 3.9 & & & \\
\hline & СТ05 & $\mathrm{CT}$ & 6.7925 & 5.2132 & -5028 & $0-0.5$ & 9 & 23.0 & -26.3 & 180 \\
\hline
\end{tabular}




\section{ACCEPTED MANUSCRIPT}

Fig. 1

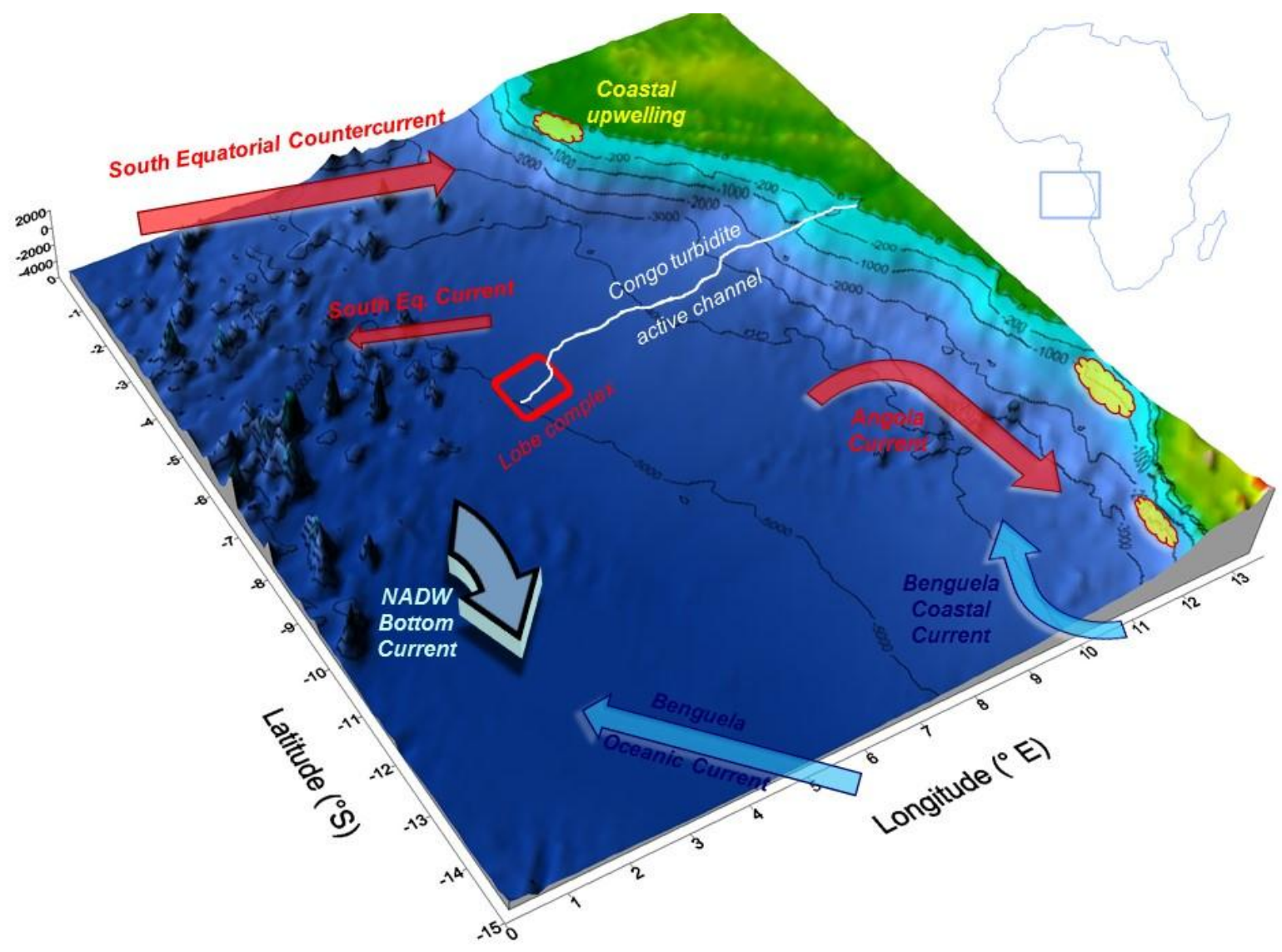

Fig. 2 


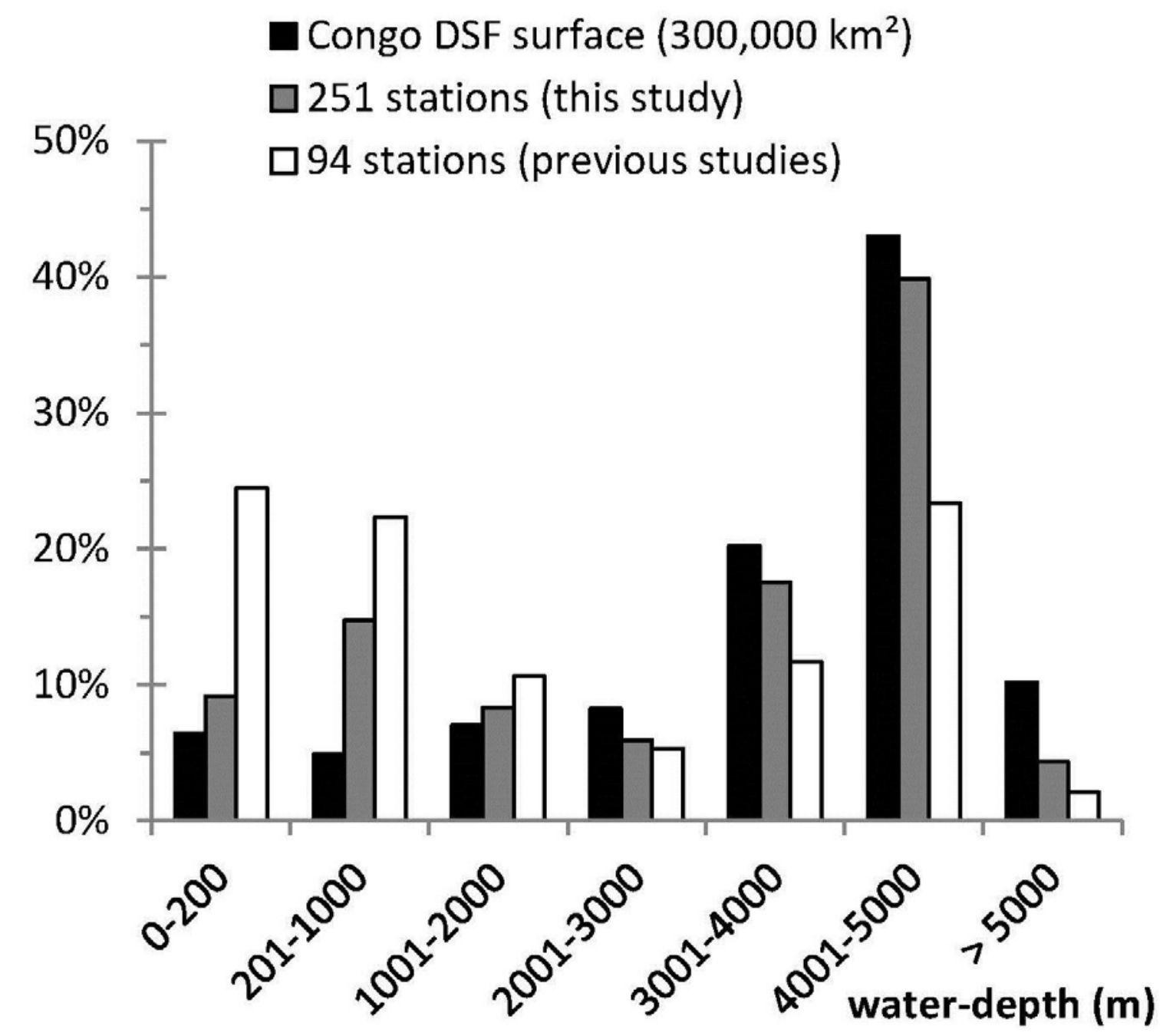

Fig. 3a 


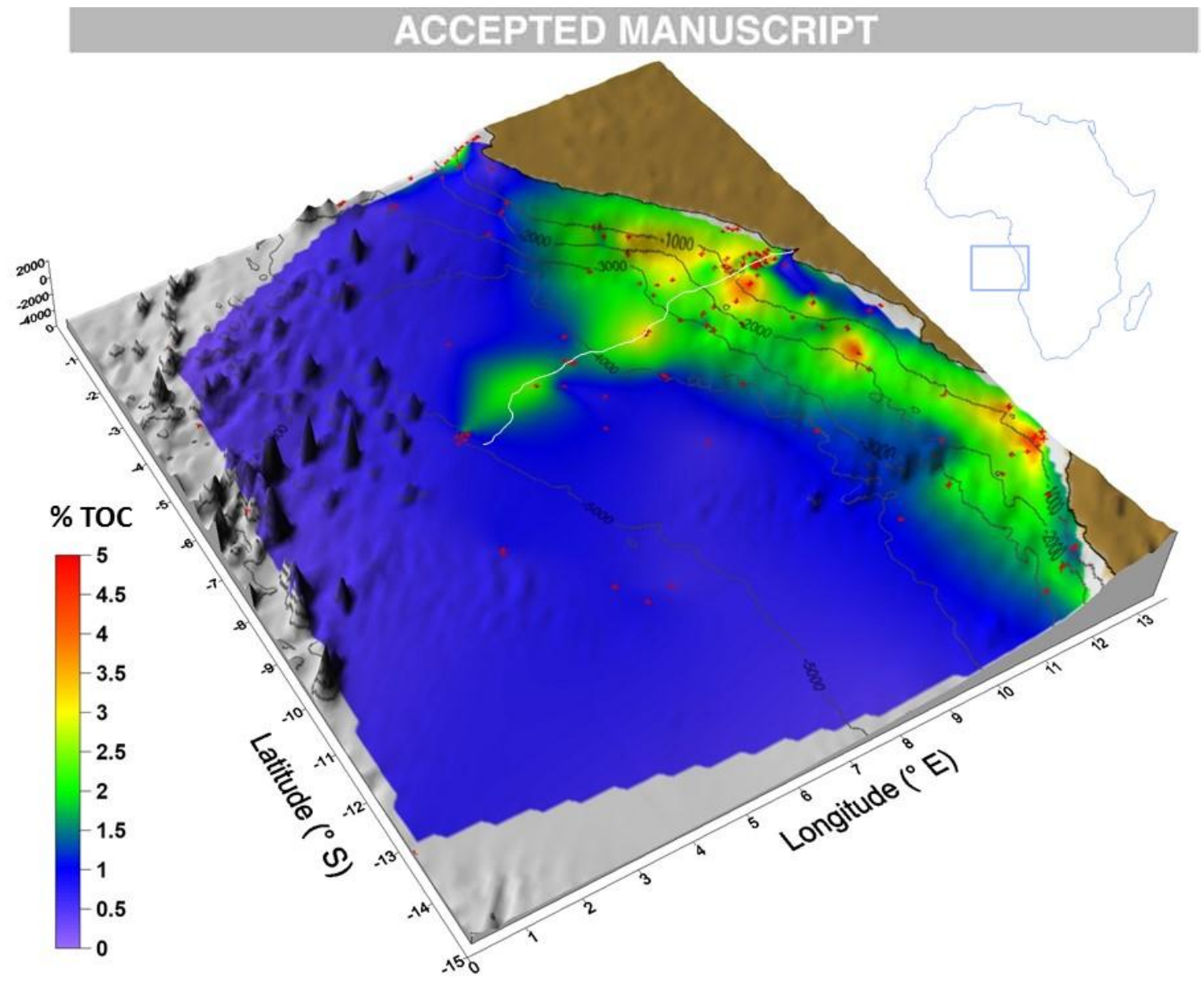

Fig. 3b 


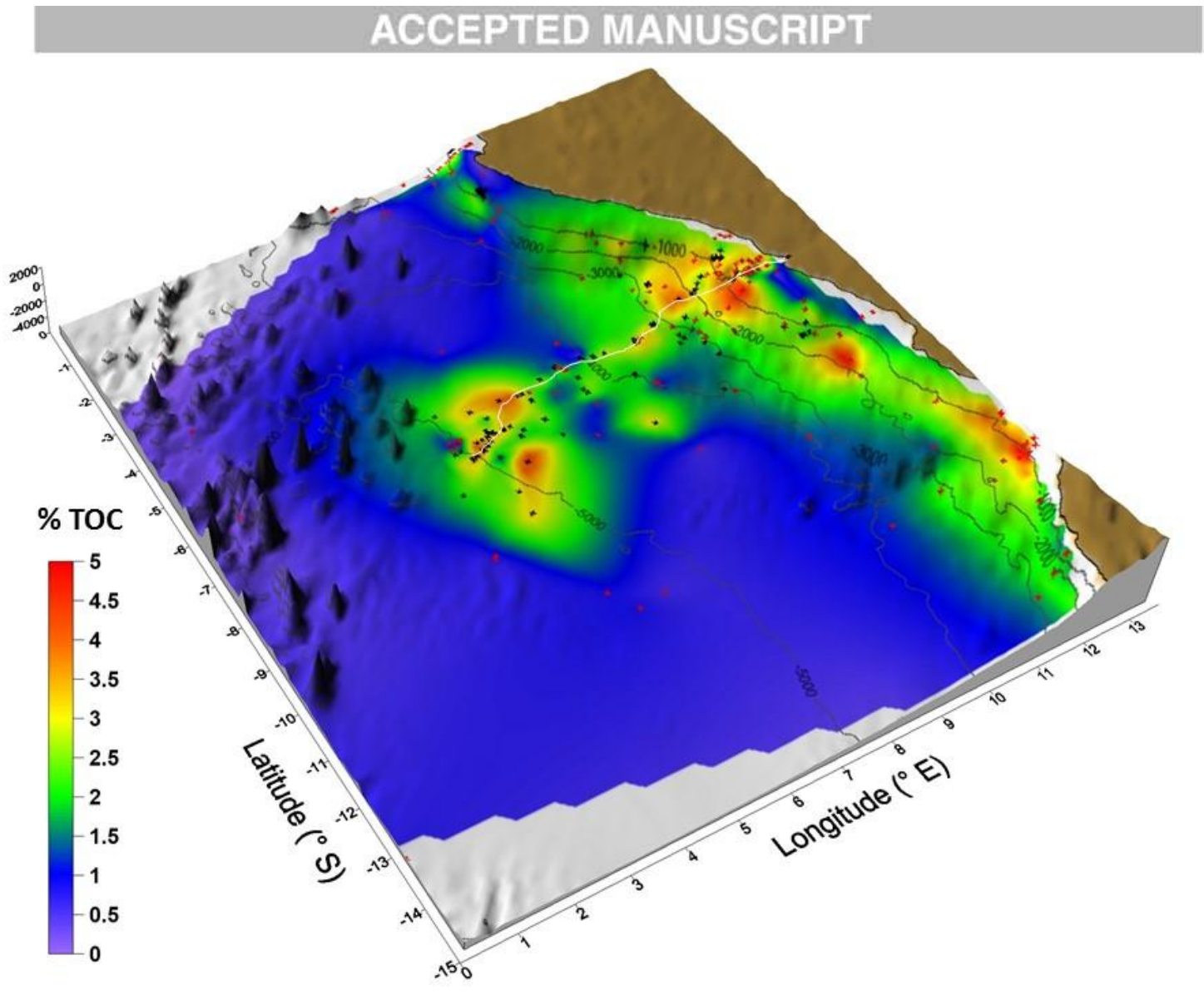

Fig. 4

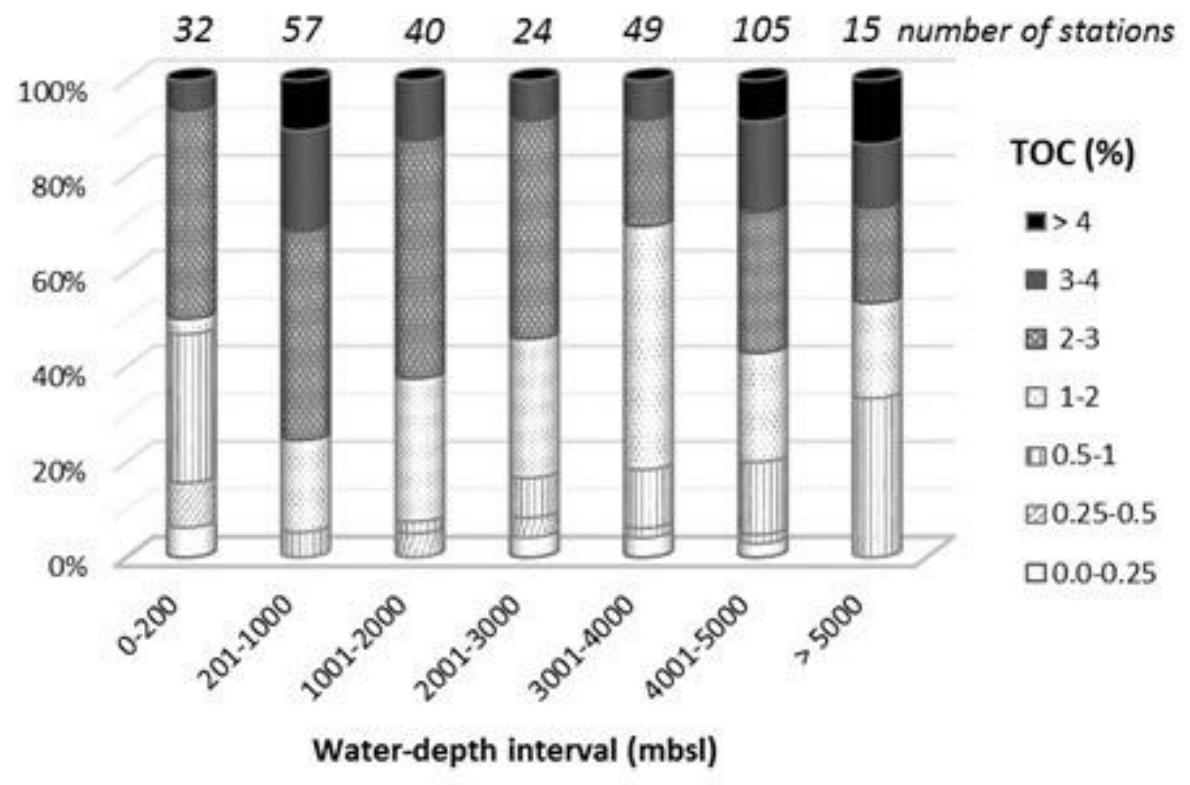




\section{ACCEPTED MANUSCRIPT}

Fig. 5

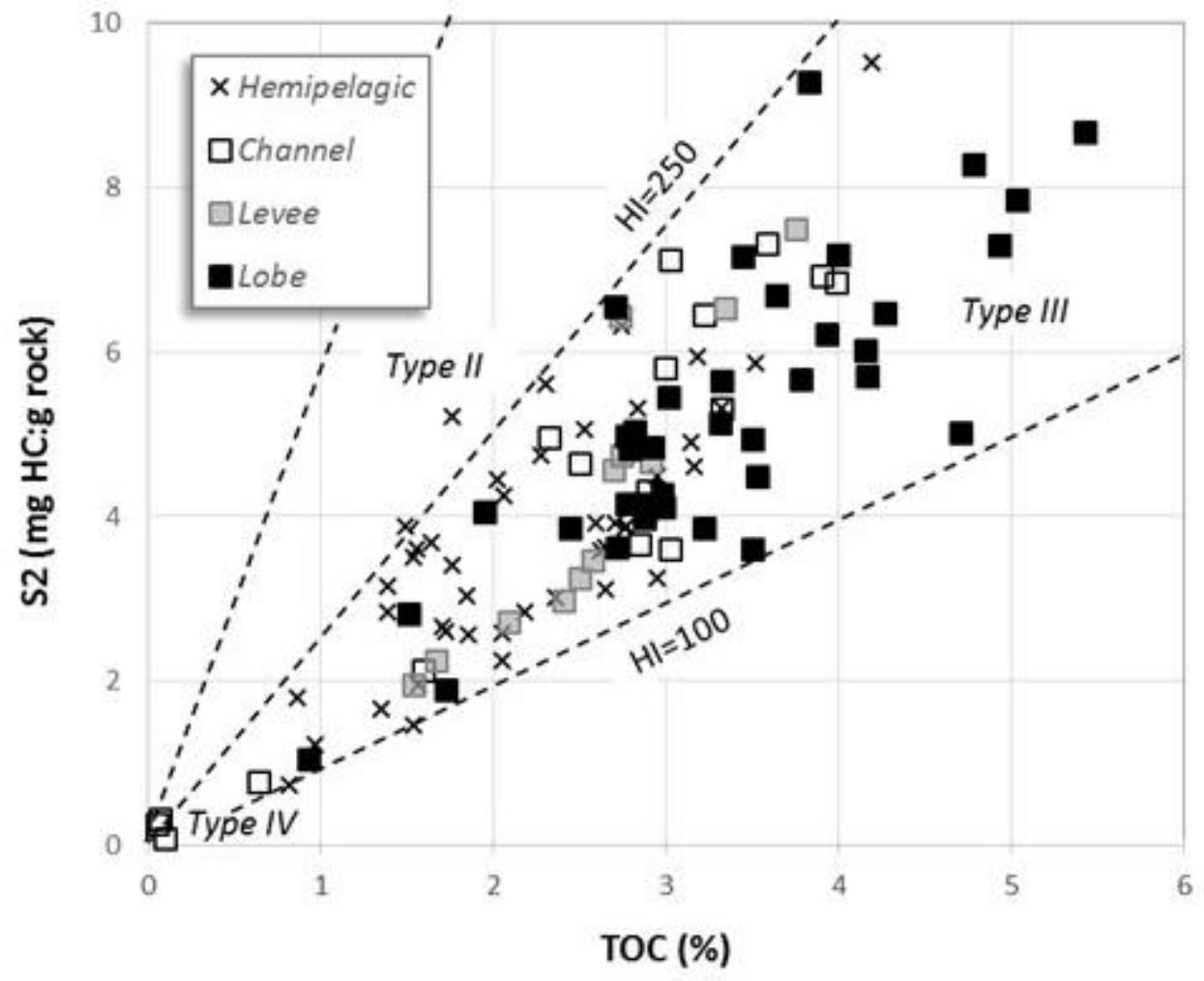

Fig. 6 


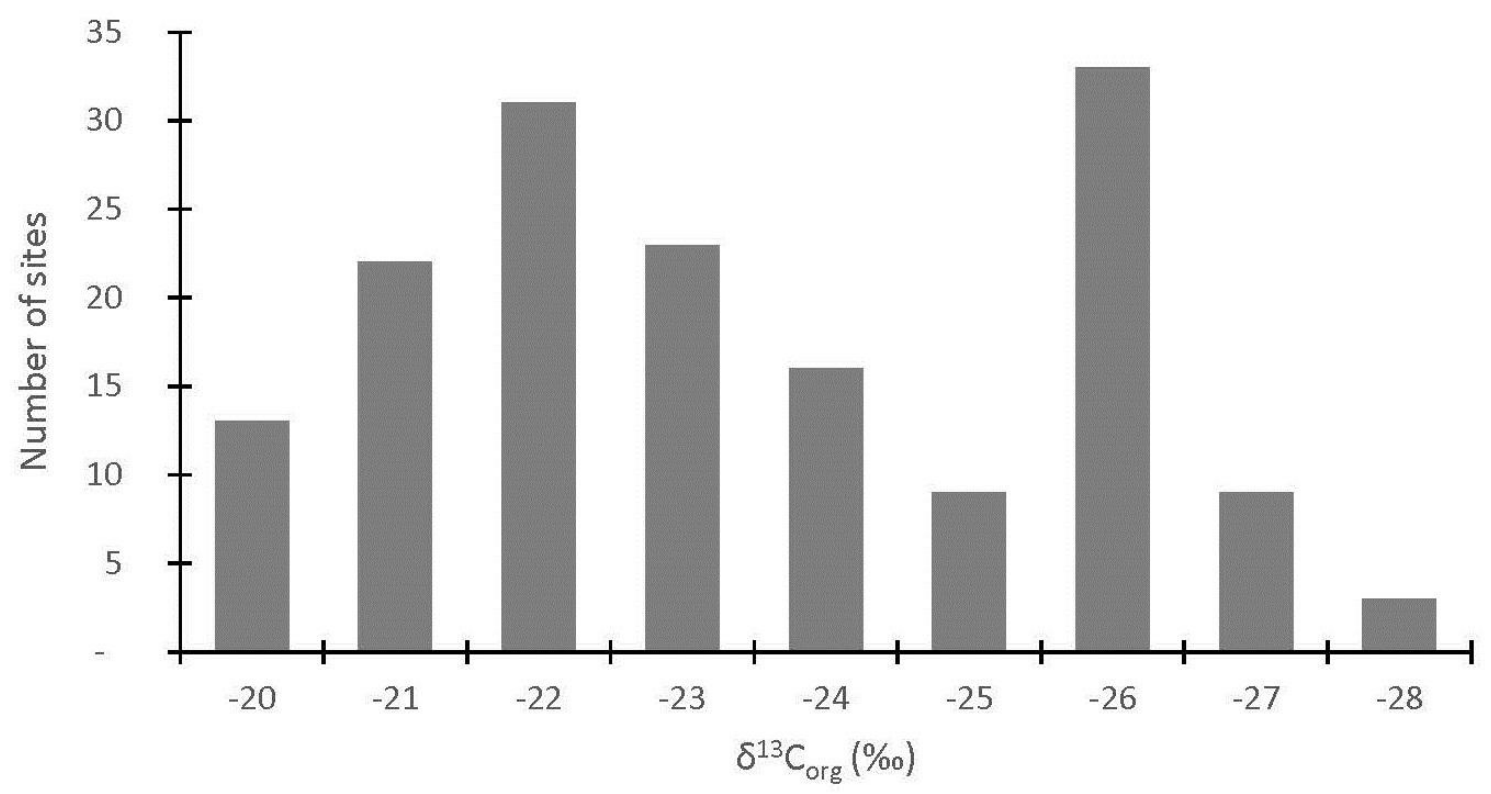

Fig. 7

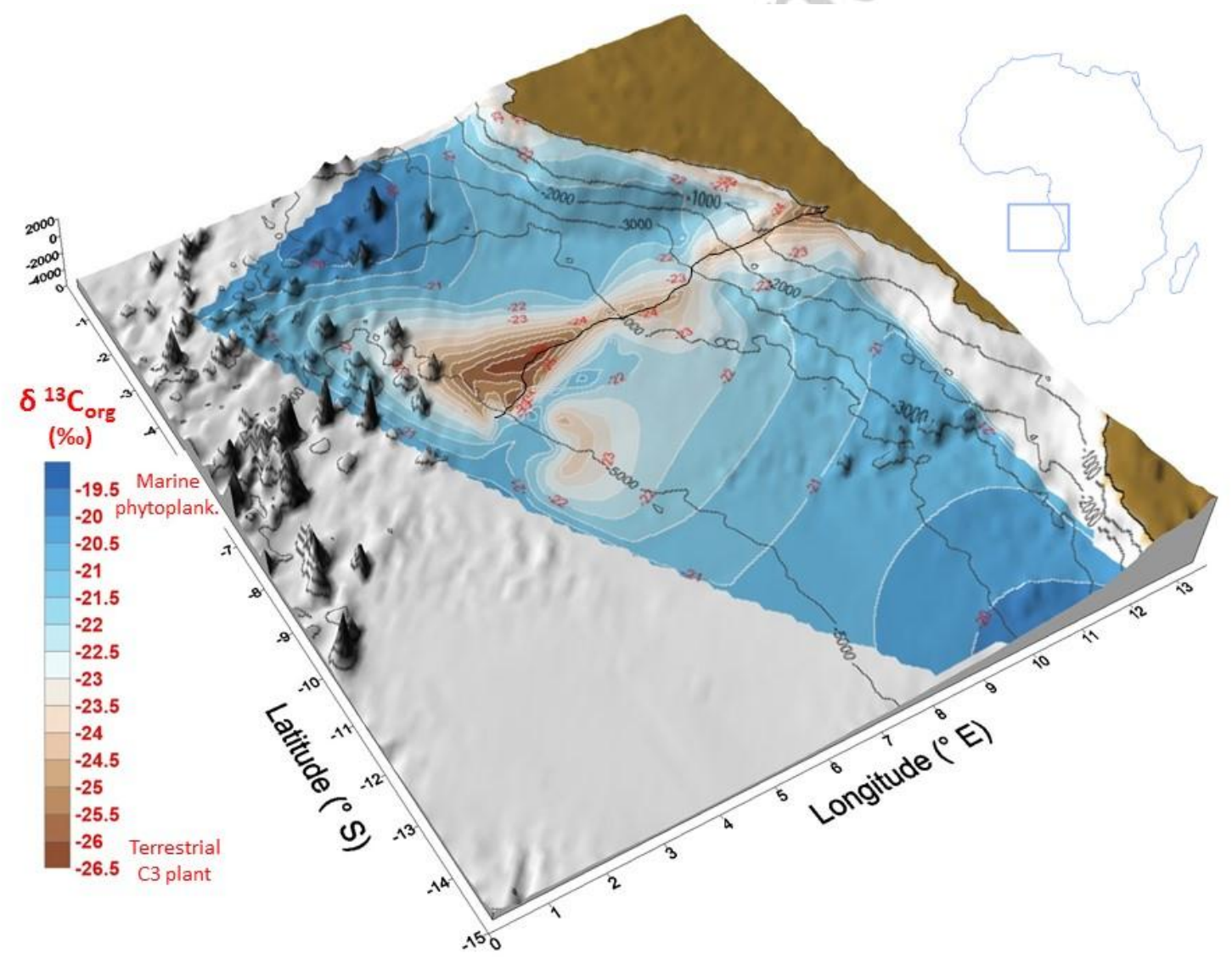


Fig. 8

Distance (in km) from turbidite active channel - 0-25 25-50 50-100 100-150

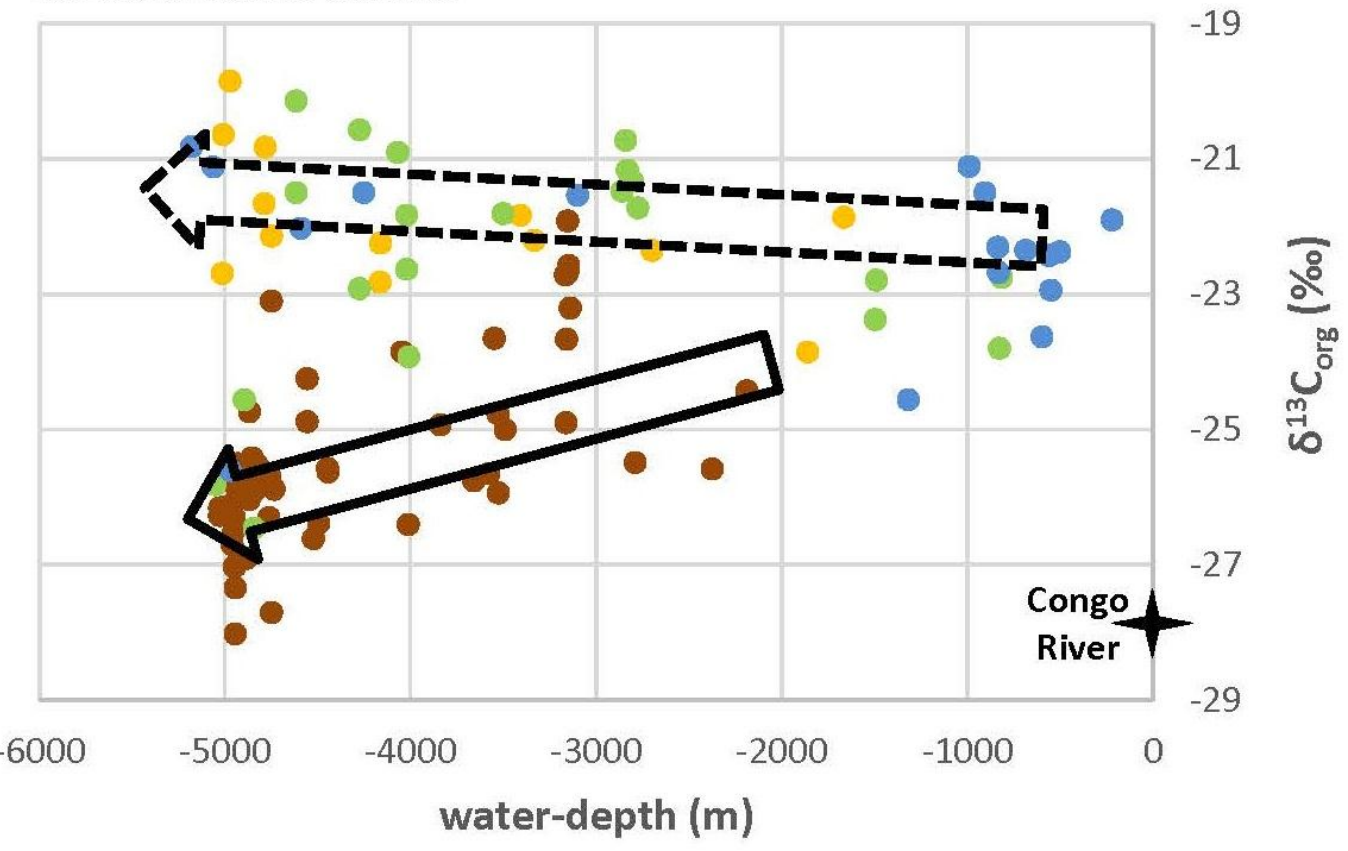

Fig. 9 


\section{ACCEPTED MANUSCRIPT}

Hydrogen Index (mg HC/g TOC)

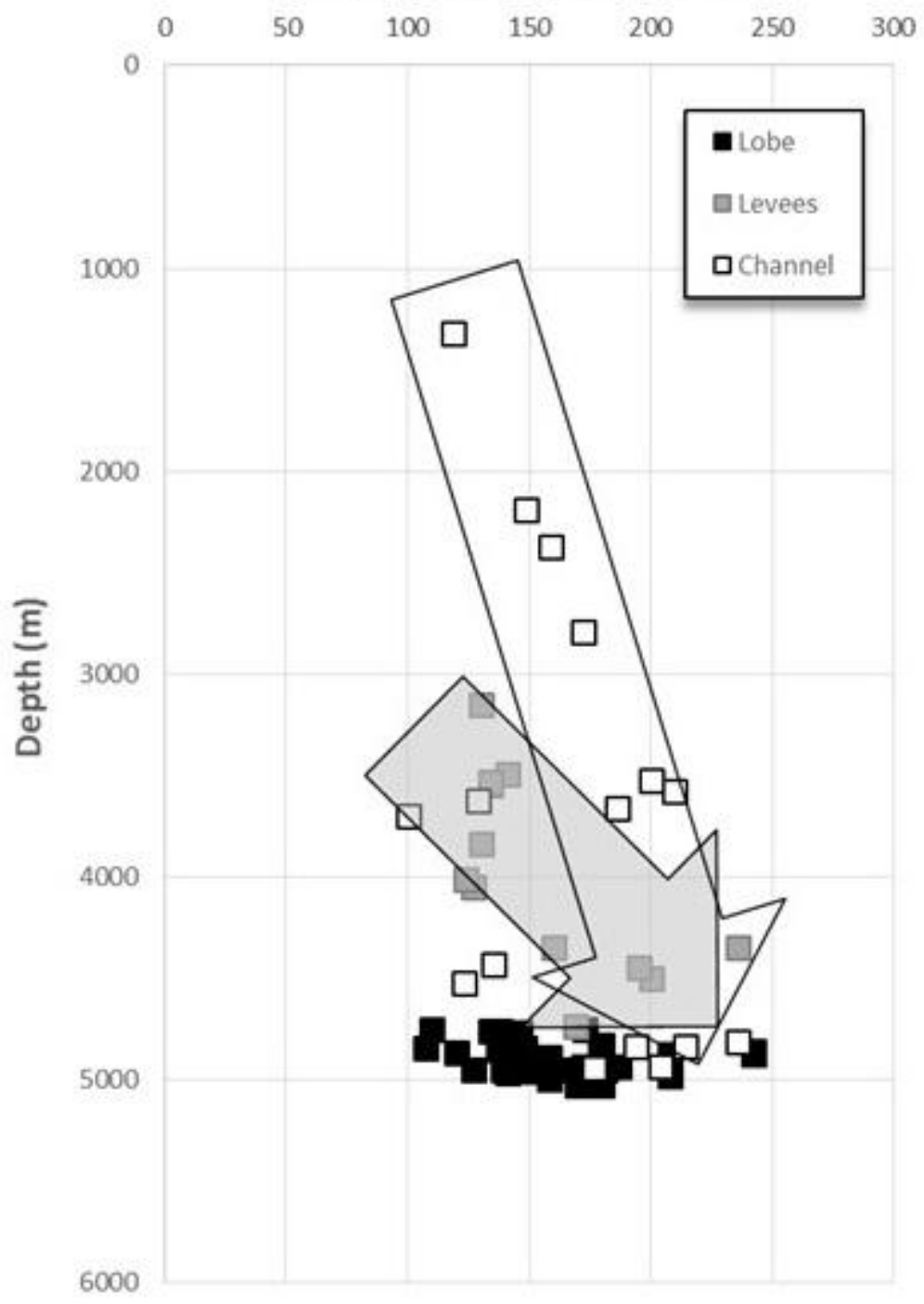

